\title{
LEVEL II SCOUR ANALYSIS FOR BRIDGE 7 (CHARTH00010007) on TOWN HIGHWAY 1, crossing MAD BROOK, CHARLESTON, VERMONT
}

U.S. Geological Survey Open-File Report 97-213

Prepared in cooperation with

VERMONT AGENCY OF TRANSPORTATION and

FEDERAL HIGHWAY ADMINISTRATION 


\section{LEVEL II SCOUR ANALYSIS FOR BRIDGE 7 (CHARTH00010007) on TOWN HIGHWAY 1, crossing MAD BROOK, CHARLESTON, VERMONT}

By Erick M. Boehmler and Matthew A. Weber

U.S. Geological Survey Open-File Report 97-213

Prepared in cooperation with

VERMONT AGENCY OF TRANSPORTATION

and

FEDERAL HIGHWAY ADMINISTRATION 


\title{
U.S. DEPARTMENT OF THE INTERIOR BRUCE BABBITT, Secretary
}

\author{
U.S. GEOLOGICAL SURVEY \\ Gordon P. Eaton, Director
}

For additional information write to:

District Chief

U.S. Geological Survey 361 Commerce Way

Pembroke, NH 03275-3718
Copies of this report may be purchased from:

U.S. Geological Survey

Branch of Information Services

Open-File Reports Unit

Box 25286

Denver, CO 80225-0286 


\section{CONTENTS}

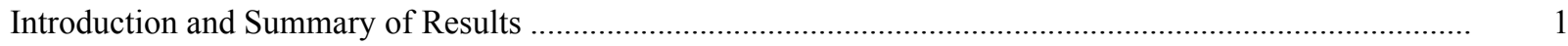

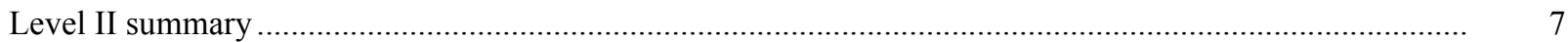

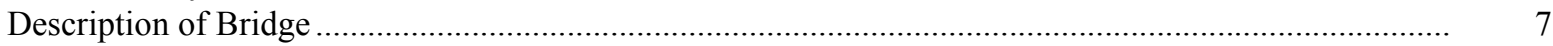

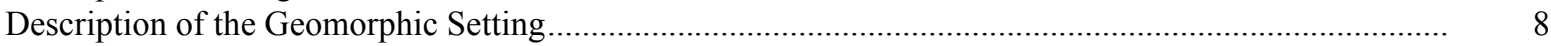

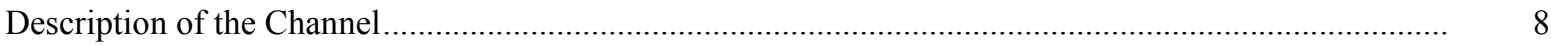

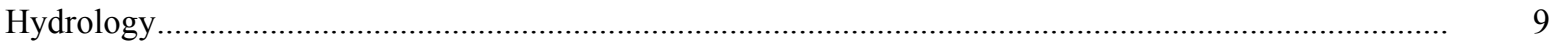

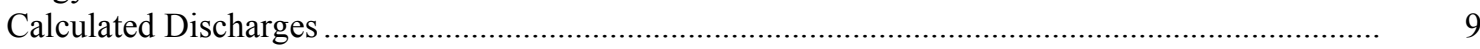

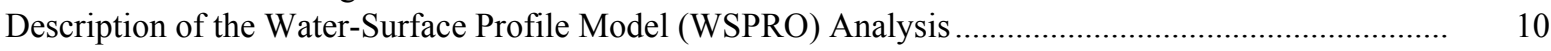

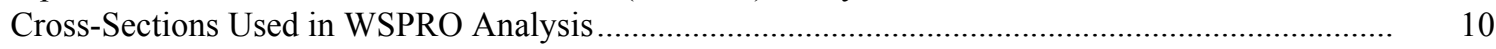

Data and Assumptions Used in WSPRO Model ..................................................................... 11

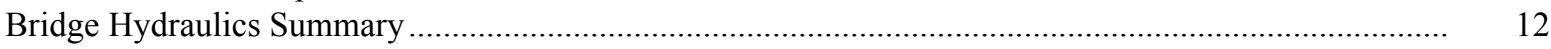

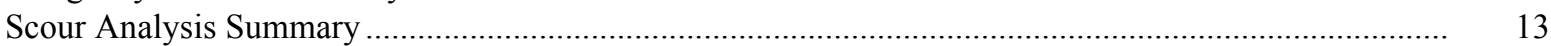

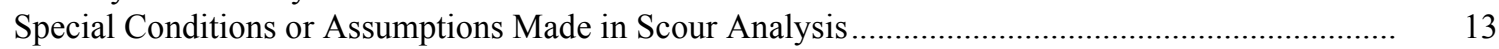

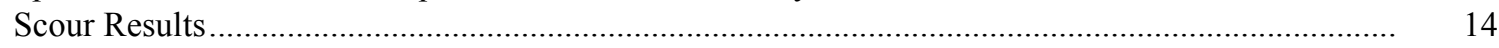

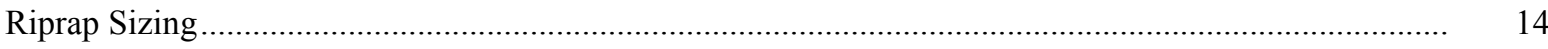

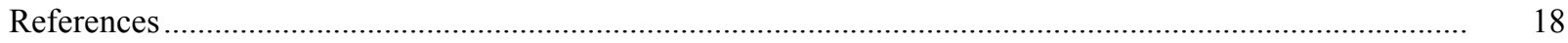

Appendixes:

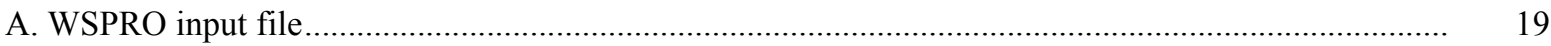

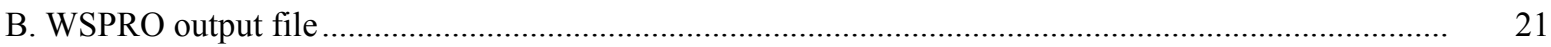

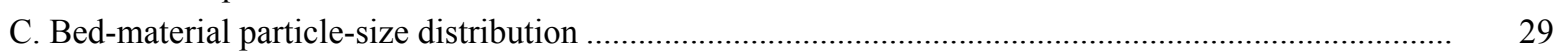

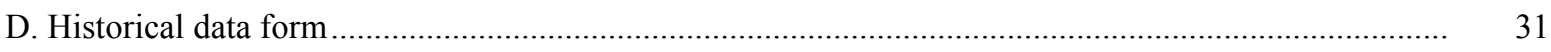

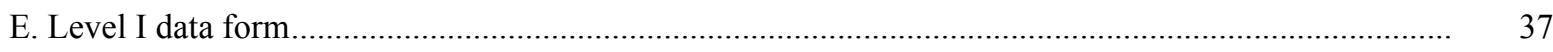

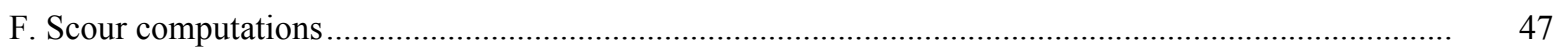

\section{FIGURES}

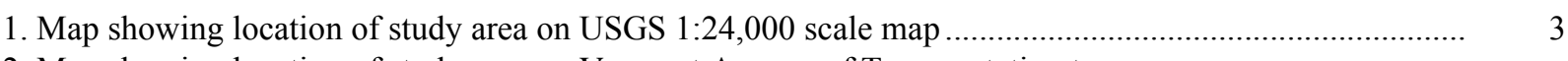

2. Map showing location of study area on Vermont Agency of Transportation town
highway map

3. Structure CHARTH00010007 viewed from upstream (October 28, 1994) ............................................ 5

4. Downstream channel viewed from structure CHARTH00010007 (October 28, 1994). ........................... 5

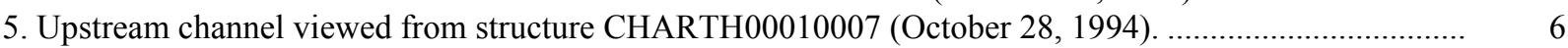

6. Structure CHARTH00010007 viewed from downstream (October 28, 1994), ...................................... 6

7. Water-surface profiles for the 100- and 500-year discharges at structure

CHARTH00010007 on Town Highway 1, crossing Mad Brook,

Charleston, Vermont.

8. Scour elevations for the 100-year discharge at structure CHARTH00010007 on Town Highway 1, crossing Mad Brook, Charleston, Vermont.

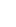

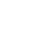

5

\section{TABLES}

1. Remaining footing/pile depth at abutments for the 100-year discharge at structure

CHARTH00010007 on Town Highway 1, crossing Mad Brook,

Charleston, Vermont

2. Remaining footing/pile depth at abutments for the 500-year discharge at structure

CHARTH00010007 on Town Highway 1, crossing Mad Brook,

Charleston, Vermont..... 


\begin{tabular}{|c|c|c|}
\hline Multiply & By & To obtain \\
\hline \multicolumn{3}{|c|}{ Length } \\
\hline inch (in.) & 25.4 & millimeter (mm) \\
\hline foot $(\mathrm{ft})$ & 0.3048 & meter $(\mathrm{m})$ \\
\hline mile (mi) & 1.609 & kilometer (km) \\
\hline \multicolumn{3}{|c|}{ Slope } \\
\hline foot per mile ( $\mathrm{ft} / \mathrm{mi})$ & 0.1894 & meter per kilometer $(\mathrm{m} / \mathrm{km})$ \\
\hline \multicolumn{3}{|c|}{ Area } \\
\hline square mile $\left(\mathrm{mi}^{2}\right)$ & 2.590 & square kilometer $\left(\mathrm{km}^{2}\right)$ \\
\hline \multicolumn{3}{|c|}{ Volume } \\
\hline cubic foot $\left(\mathrm{ft}^{3}\right)$ & $\begin{array}{l}0.02832 \\
\text { Velocity and Flow }\end{array}$ & cubic meter $\left(\mathrm{m}^{3}\right)$ \\
\hline foot per second (ft/s) & 0.3048 & meter per second $(\mathrm{m} / \mathrm{s})$ \\
\hline cubic foot per second $\left(\mathrm{ft}^{3} / \mathrm{s}\right)$ & 0.02832 & cubic meter per second $\left(\mathrm{m}^{3} / \mathrm{s}\right)$ \\
\hline $\begin{array}{l}\text { cubic foot per second per } \\
\text { square mile } \\
{\left[\left(\mathrm{ft}^{3} / \mathrm{s}\right) / \mathrm{mi}^{2}\right]}\end{array}$ & 0.01093 & $\begin{array}{l}\text { cubic meter per } \\
\text { second per square } \\
\text { kilometer }\left[\left(\mathrm{m}^{3} / \mathrm{s}\right) / \mathrm{km}^{2}\right]\end{array}$ \\
\hline
\end{tabular}

OTHER ABBREVIATIONS

$\begin{array}{lrlr}\mathrm{BF} & \text { bank full } & \text { LWW } & \text { left wingwall } \\ \mathrm{cfs} & \text { cubic feet per second } & \text { MC } & \text { main channel } \\ \mathrm{D}_{50} & \text { median diameter of bed material } & \text { RAB } & \text { right abutment } \\ \mathrm{DS} & \text { downstream } & \text { RABUT } & \text { face of right abutment } \\ \mathrm{elev} & \text { elevation } & \text { RB } & \text { right bank } \\ \mathrm{f} / \mathrm{p} & \text { flood plain } & \text { ROB } & \text { right overbank } \\ \mathrm{ft} & \text { square feet } & \text { RWW } & \text { right wingwall } \\ \mathrm{ft} / \mathrm{ft} & \text { feet per foot } & \text { TH } & \text { town highway } \\ \mathrm{JCT} & \text { junction } & \text { UB } & \text { under bridge } \\ \mathrm{LAB} & \text { left abutment } & \text { US } & \text { upstream } \\ \mathrm{LABUT} & \text { face of left abutment } & \text { USGS } & \text { United States Geological Survey } \\ \text { LB } & \text { left bank } & \text { VTAOT Vermont Agency of Transportation } \\ \text { LOB } & \text { left overbank } & \text { WSPRO } & \text { water-surface profile model }\end{array}$

In this report, the words "right" and "left" refer to directions that would be reported by an observer facing downstream. Sea level: In this report, "sea level" refers to the National Geodetic Vertical Datum of 1929-- a geodetic datum derived from a general adjustment of the first-order level nets of the United States and Canada, formerly called Sea Level Datum of 1929.

In the appendices, the above abbreviations may be combined. For example, USLB would represent upstream left bank. 


\title{
LEVEL II SCOUR ANALYSIS FOR BRIDGE 7 (CHARTH00010007) ON TOWN HIGHWAY 1, CROSSING MAD BROOK, CHARLESTON, VERMONT
}

\author{
By Erick M. Boehmler and Matthew A. Weber
}

\section{INTRODUCTION AND SUMMARY OF RESULTS}

This report provides the results of a detailed Level II analysis of scour potential at structure CHARTH00010007 on town highway 1 crossing Mad Brook, Charleston, Vermont (figures 1-8). A Level II study is a basic engineering analysis of the site, including a quantitative analysis of stream stability and scour (U.S. Department of Transportation, 1993). Results of a Level I scour investigation also are included in Appendix E of this report. A Level I investigation provides a qualitative geomorphic characterization of the study site. Information on the bridge, gleaned from Vermont Agency of Transportation (VTAOT) files, was compiled prior to conducting Level I and Level II analyses and is found in Appendix D.

The site is in the White Mountain section of the New England physiographic province in north-central Vermont in the town of Charleston. The 6.59- $\mathrm{mi}^{2}$ drainage area is in a predominantly rural and forested basin. In the vicinity of the study site, the surface cover is pasture except for the upstream left bank, which is forest. The stream banks are tree covered upstream and on the downstream left bank side.

In the study area, Mad Brook has an incised, sinuous channel with a slope of approximately $0.01 \mathrm{ft} / \mathrm{ft}$, an average channel top width of $41 \mathrm{ft}$ and an average channel depth of $5 \mathrm{ft}$. The predominant channel bed materials range from gravel to boulders with a median grain size $\left(\mathrm{D}_{50}\right)$ of $105 \mathrm{~mm}(0.344 \mathrm{ft})$. The geomorphic assessment at the time of the Level I and Level II site visit on October 28, 1994, indicated that the reach was stable.

The town highway 1 crossing of Mad Brook is a 27-ft-long, two-lane bridge consisting of one 25-foot concrete T-beam span (Vermont Agency of Transportation, written communication, August 4, 1994). The bridge is supported by vertical, concrete abutments with wingwalls. The channel is skewed approximately 10 degrees to the opening. The opening-skew-to-roadway computed from surveyed data is 5 degrees, but historical bridge records indicate this angle is closer to 10 degrees. 
There was scour evident during the Level I assessment due to the presence of two subfootings at the base of each abutment wall. Although the subfootings may have been constructed at the same time as the abutment walls, the subfootings may have been constructed at a later time in response to streambed degradation under the bridge. The right abutment was noted as undermined during the Level I assessment. Scour protection measures at the site were type- 1 stone fill (less than 12 inches diameter) on the upstream right and downstream road embankments and type-2 stone fill on each wingwall and the downstream left bank. Additional details describing conditions at the site are included in the Level II Summary and Appendices D and E.

Scour depths and rock rip-rap sizes were computed using the general guidelines described in Hydraulic Engineering Circular 18 (Richardson and others, 1995). Total scour at a highway crossing is comprised of three components: 1) long-term streambed degradation; 2) contraction scour (due to accelerated flow caused by a reduction in flow area at a bridge) and; 3) local scour (caused by accelerated flow around piers and abutments). Total scour is the sum of the three components. Equations are available to compute depths for contraction and local scour and a summary of the results of these computations follows.

Contraction scour for all modelled flows ranged from 0.0 to $0.3 \mathrm{ft}$. The worst-case contraction scour occurred at the incipient overtopping discharge, which was less than the 100 -year discharge. Abutment scour ranged from 6.2 to $9.4 \mathrm{ft}$. The worst-case abutment scour for the right abutment was 9.4 feet at the 100 -year discharge. The worst-case abutment scour for the left abutment was 8.6 feet at the incipient overtopping discharge. Additional information on scour depths and depths to armoring are included in the section titled "Scour Results". Scoured-streambed elevations, based on the calculated scour depths, are presented in tables 1 and 2. A cross-section of the scour computed at the bridge is presented in figure 8 . Scour depths were calculated assuming an infinite depth of erosive material and a homogeneous particle-size distribution.

It is generally accepted that the Froehlich equation (abutment scour) gives "excessively conservative estimates of scour depths" (Richardson and others, 1995, p. 47). Usually, computed scour depths are evaluated in combination with other information including (but not limited to) historical performance during flood events, the geomorphic stability assessment, existing scour protection measures, and the results of the hydraulic analyses. Therefore, scour depths adopted by VTAOT may differ from the computed values documented herein. 


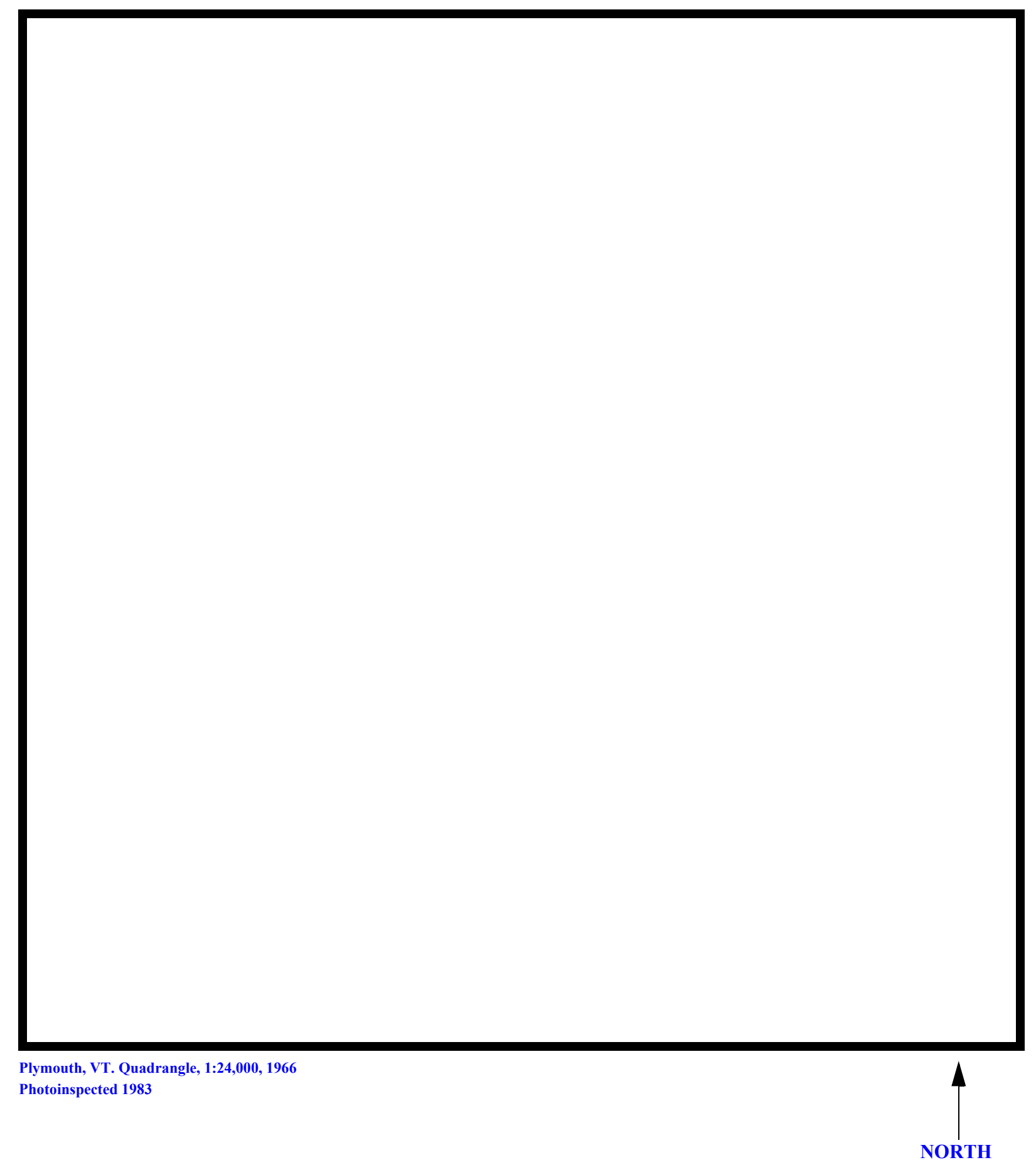

Figure 1. Location of study area on USGS 1:24,000 scale map. 
Figure 2. Location of study area on Vermont Agency of Transportation town highway map. 

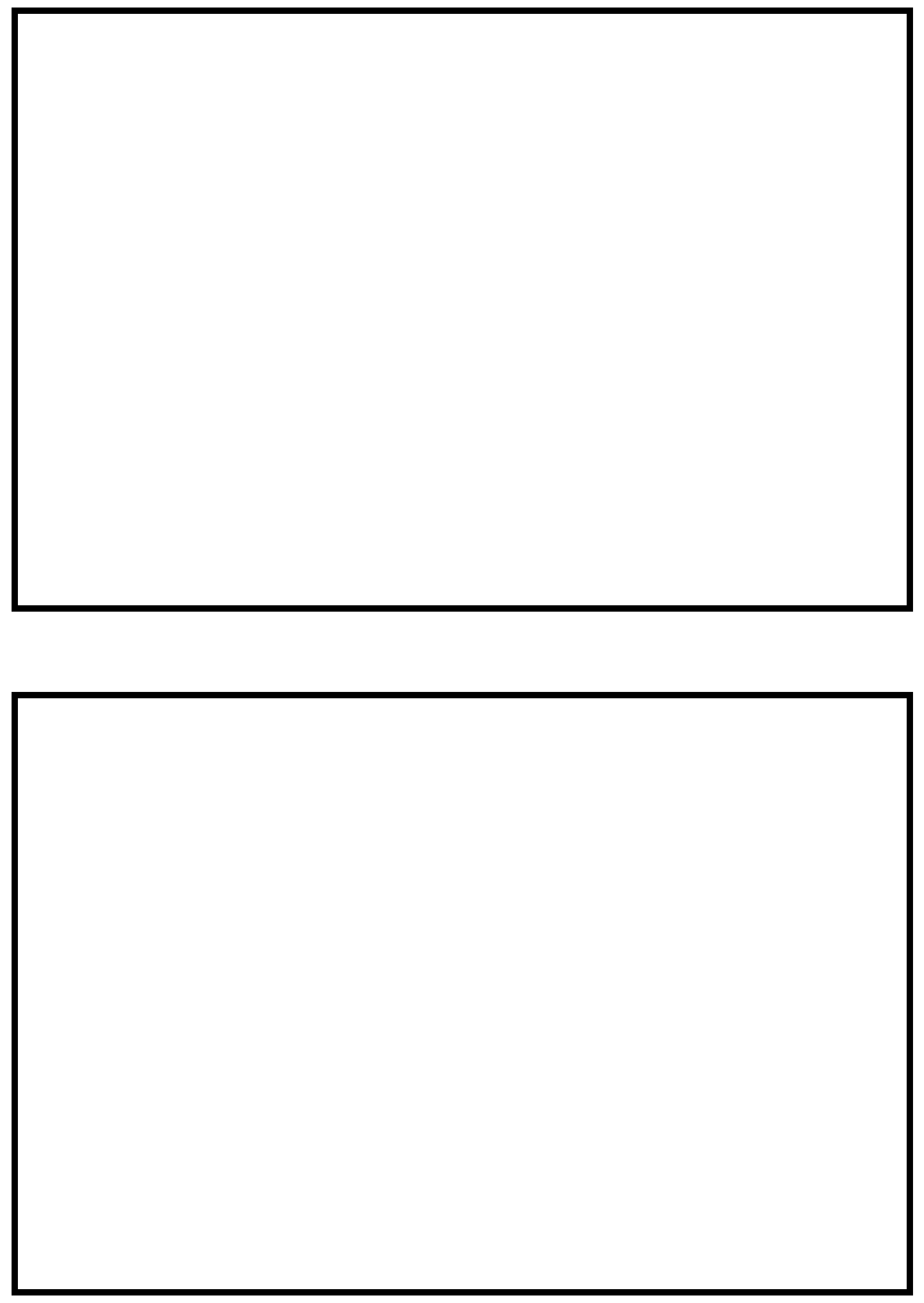

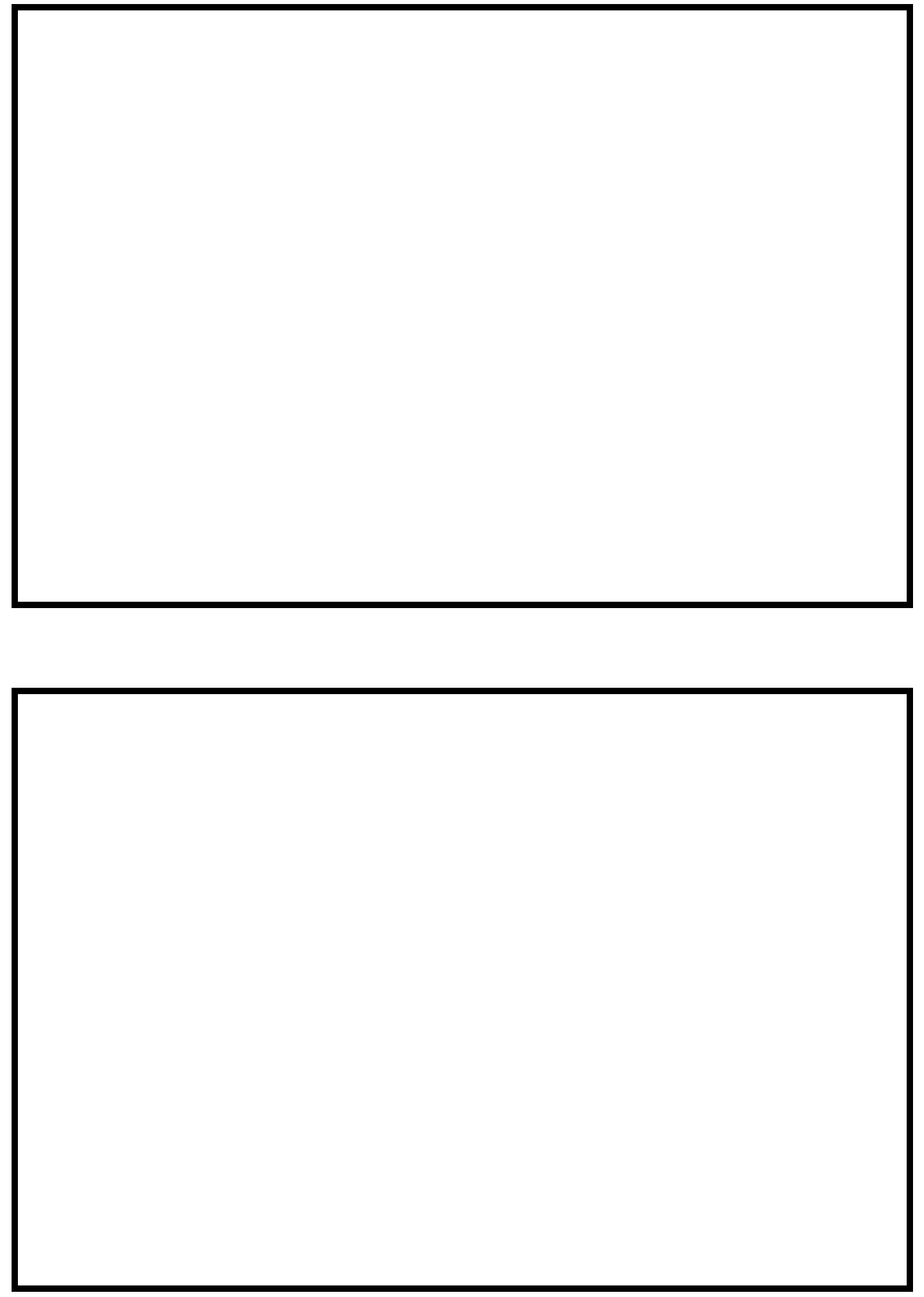


\section{LEVEL II SUMMARY}

\begin{tabular}{llllll} 
Structure Number & CHARTH00010007 & Stream & \multicolumn{2}{c}{ Mad Brook } & \\
& Soad & TH 1 & District & 9
\end{tabular}

\section{Description of Bridge}

Bridge length $\stackrel{27}{2} \boldsymbol{f t}$ Bridge width $\stackrel{23.5}{f t}$ Max span length $\stackrel{25}{ } \boldsymbol{f t}$ Alignment of bridge to road (on curve or straight)

Abutment type Vertical, concrete

\section{Stone fill on ab
and both dow
downstream.} sil

\section{Embankment type \\ Dato af incnortion} Straight

\section{Sloping}

$10 / 28 / 94$

No stone fill on abutments. Type-1 was noted on the upstream right and both downstream road embankments. Type-2 was noted on each wingwall and the left bank

Abutments and wingwalls are concrete. There are twostep footings exposed at the toe of each abutment wall. The subfootings were undermined at the downstream end of the right abutment.

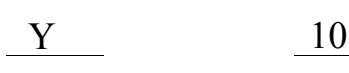

Is bridge skewed to flood flow according to $\mathrm{N} \quad$ survey? Angle

Debris accumulation on bridge at time of Level I or Level II site visit:

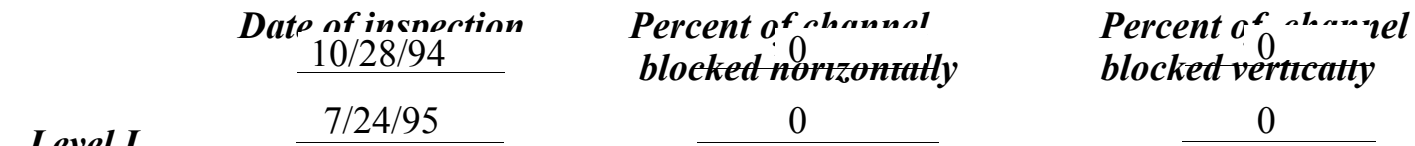

Level I

Low. The reach upstream is straight and laterally stable with old

Level II growth trees on both banks.

Potential for debris

None evident on 10/28/94 or 7/24/95.

Dosrriho anv fonturos noar ar at tho hridos that mav affort flow, (includo ohsorvation dato) 


\section{Description of the Geomorphic Setting}

General topography The channel is located in a moderate relief valley setting. The gradient is steeper upstream than downstream and wider flood plains exist downstream.

Geomorphic conditions at bridge site: downstream (DS), upstream (US)

Date of inspection $\quad 10 / 28 / 94$

DS left: $\quad$ Steep channel bank to a narrow flood plain and a steep valley wall.

DS right: $\quad$ Moderately sloped bank to a narrow flood plain.

US left: $\quad$ Steep channel bank to a narrow flood plain and a steep valley wall.

US right: $\quad$ Steep channel bank to a narrow flood plain.

\section{Description of the Channel}

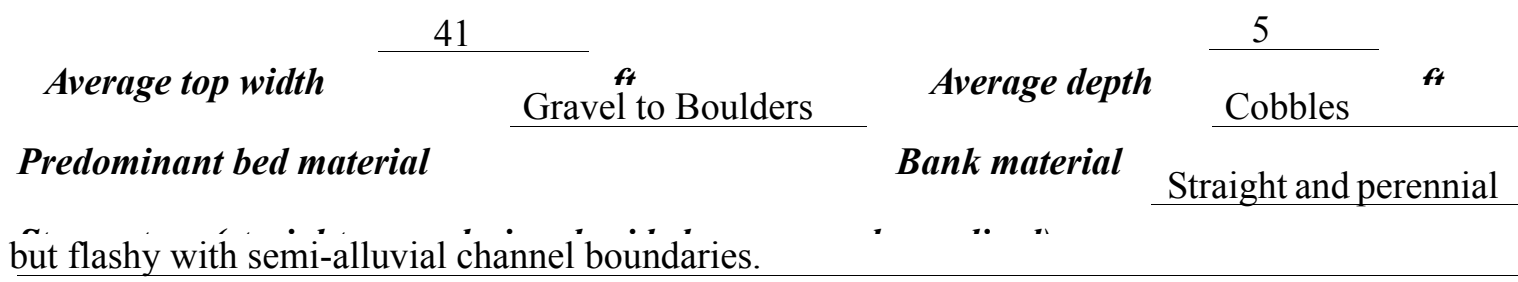

$10 / 28 / 94$

Vegetative co ${ }^{1}$ Pasture with trees along the immediate bank."

DS left: $\quad$ Pasture with trees and brush along the immediate bank.

DS right: $\quad$ Trees.

US left: $\quad$ Grass and brush with trees along the immediate bank.

US right: $\quad \underline{\mathrm{Y}}$

Do banks appear stable? -

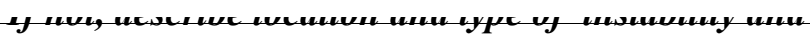

date of observatton.

The assessment of

10/28/94 noted many large boulders scattered in the channel upstream. Describe any obstructions in channel and date of observation. 


\section{Hydrology}

Drainage area $\stackrel{6.59}{\mathrm{mi}^{2}}$

Percentage of drainage area in physiographic provinces: (approximate)

Physiographic province/section

New England / White Mountain
Percent of drainage area 100

Is drainage area considered rural or urban? — Rural _ Describe any significant urbanization:

No

Is there a USGS gage on the stream of interest?

USGS gage description

USGS gage number

Gage drainage area

$m i^{2}$

No

Is there a lake/p -

. . . . . . . . . . . . .

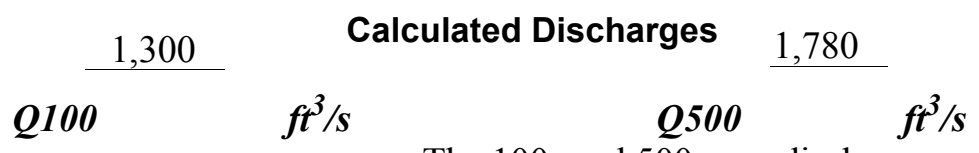

The 100- and 500-year discharges noted above are

the same as those applied for bridge number 19 over Mad Brook in Charleston. The watershed area above this site and bridge 19 practically are the same. The 100 - and 500-year discharges at bridge 19 were based on a range determined from several empirical relationships (Benson, 1962;

FHWA, 1983; Johnson and Tasker, 1974; Johnson and Laraway, unpublished draft, 1971; Potter, 1957; and Talbot, 1887). The values from the FHWA method were seleted due to the central tendency of the relationship with the others. 


\section{Description of the Water-Surface Profile Model (WSPRO) Analysis}

Datum for WSPRO analysis (USGS survey, sea level, VTAOT plans)

USGS survey

Datum tie between USGS survey and VTAOT plans

None

Description of reference marks used to determine USGS datum. $\quad$ RM1 is the center point

of a chiseled "X" on top of the concrete bridge deck near the upstream left corner (elev. 501.51

$\mathrm{ft}$, arbitrary survey datum). RM2 is the center point of a chiseled " $\mathrm{X}$ " on top of the concrete

bridge deck near the downstream right corner (elev. $500.97 \mathrm{ft}$, arbitrary survey datum).

\section{Cross-Sections Used in WSPRO Analysis}

\begin{tabular}{|c|c|c|c|}
\hline${ }^{1}$ Cross-section & $\begin{array}{c}\text { Section } \\
\text { Reference } \\
\text { Distance } \\
\text { (SRD) in feet }\end{array}$ & $\begin{array}{c}{ }^{2} \text { Cross-section } \\
\text { development }\end{array}$ & Comments \\
\hline EXIT1 & -22 & 1 & Exit section \\
\hline FULLV & 0 & 2 & $\begin{array}{l}\text { Downstream Full-valley } \\
\text { section (Templated from } \\
\text { EXIT1) }\end{array}$ \\
\hline BRIDG & 0 & 1 & Bridge section \\
\hline RDWAY & 13 & 1 & Road Grade section \\
\hline APTEM & 47 & 1 & $\begin{array}{l}\text { Approach section as sur- } \\
\text { veyed (Used as a tem- } \\
\text { plate) }\end{array}$ \\
\hline APPRO & 50 & 2 & $\begin{array}{l}\text { Modelled Approach sec- } \\
\text { tion (Templated from } \\
\text { APTEM) }\end{array}$ \\
\hline
\end{tabular}

${ }^{1}$ For location of cross-sections see plan-view sketch included with Level I field form, Appendix E. For more detail on how cross-sections were developed see WSPRO input file. 


\section{Data and Assumptions Used in WSPRO Model}

Hydraulic analyses of the reach were done by use of the Federal Highway Administration's WSPRO step-backwater computer program (Shearman and others, 1986, and Shearman, 1990). The analyses reported herein reflect conditions existing at the site at the time of the study. Furthermore, in the development of the model it was necessary to assume no accumulation of debris or ice at the site. Results of the hydraulic model are presented in the Bridge Hydraulic Summary, Appendix B, and figure 7.

Channel roughness factors (Manning's " $n$ ") used in the hydraulic model were estimated using field inspections at each cross section following the general guidelines described by Arcement and Schneider (1989). Final adjustments to the values were made during the modelling of the reach. Channel " $n$ " values for the reach ranged from 0.055 to 0.065 , and overbank " $n$ " values ranged from 0.045 to 0.085 .

Downstream of this site, Mad Brook enters the Clyde River valley. However, the elevation at the location where Mad Brook enters the Clyde River is more than 20 feet below the channel elevation downstream of this site (below EXIT1) according to the topographic map (U.S. Geological Survey, 1988). Therefore, it was assumed there was no backwater from the Clyde River.

Normal depth at the exit section (EXIT1) was assumed as the starting water surface. This depth was computed by use of the slope-conveyance method outlined in the user's manual for WSPRO (Shearman, 1990). The slope used was $0.0145 \mathrm{ft} / \mathrm{ft}$ which was estimated from the topographic map (U.S. Geological Survey, 1988).

The surveyed approach section (APTEM) was moved along the approach channel slope $(0.0262 \mathrm{ft} / \mathrm{ft})$ to establish the modelled approach section (APPRO), one bridge length upstream of the bridge as recommended by Shearman and others (1986). This location also provides a consistent method for determining scour variables.

For the incipient-overtopping discharge, a vertical wall was inserted at the top of the right bank upstream. This was necessary to prevent WSPRO from computing flow on the right overbank area due to high banks adjacent to the channel. WSPRO assumes critical depth at the bridge section for the incipient-overtopping discharge. A supercritical model was developed for this discharge. After analyzing both the supercritical and subcritical profiles, it can be determined that the water surface profile does pass through critical depth within the bridge opening. Thus, the assumption of critical depth at the bridge is a satisfactory solution. 


\section{Bridge Hydraulics Summary}

$\begin{array}{lll}\text { Average bridge embankment elevation } & 501.5 \\ \text { Average low steel elevation } & 498.9 & \boldsymbol{f t}\end{array}$

100-year discharge $\quad 1,300 \quad \mathrm{ft}^{3} / \mathrm{s}$

Water-surface elevation in bridge opening $\quad 499.1 \quad f t$

Road overtopping? __ Y Discharge over road _ $66, \ldots$ s

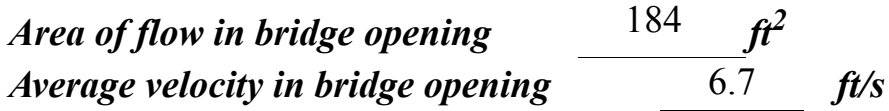

Maximum WSPRO tube velocity at bridge $\quad 8.4 \quad \mathrm{ft} / \mathrm{s}$

Water-surface elevation at Approach section with bridge 499.9

Water-surface elevation at Approach section without bridge $\quad 496.9$

Amount of backwater caused by bridge $\quad 3.0$ it

500-year discharge $\quad 1,780 \quad \mathrm{ft}^{3} / \mathrm{s}$

Water-surface elevation in bridge opening $\quad 498.9$ ft

Road overtopping? ___ Y Discharge over road _ $335, \ldots$

Area of flow in bridge opening $\quad 183 \quad \mathrm{ft}^{2}$

Average velocity in bridge opening $7.9 \mathrm{ft} / \mathrm{s}$

Maximum WSPRO tube velocity at bridge 11.0 's

Water-surface elevation at Approach section with bridge 500.3

Water-surface elevation at Approach section without bridge $\quad 497.6$

Amount of backwater caused by bridge 2.7 .

Incipient overtopping discharge $\quad 1,270 \mathrm{ft}^{3} / \mathrm{s}$

Water-surface elevation in bridge opening $495.7 \quad t$

Area of flow in bridge opening $\quad 107 \quad \mathrm{ft}^{2}$

Average velocity in bridge opening $\quad 11.8 \quad \mathrm{ft} / \mathrm{s}$

Maximum WSPRO tube velocity at bridge $14.6 \mathrm{ft} / \mathrm{s}$

Water-surface elevation at Approach section with bridge

Water-surface elevation at Approach section without bridge

499.3

Amount of backwater caused by bridge $\quad 2.5$, t 


\section{Scour Analysis Summary}

\section{Special Conditions or Assumptions Made in Scour Analysis}

Scour depths were computed using the general guidelines described in Hydraulic Engineering Circular 18 (Richardson and others, 1995). Scour depths were calculated assuming an infinite depth of erosive material and a homogeneous particle-size distribution. The results of the scour analysis are presented in tables 1 and 2 and a graph of the scour depths is presented in figure 8 .

Contraction scour was computed by use of Laursen's clear-water contraction scour equation (Richardson and others, 1995, p. 32, equation 20) for the incipient road overtopping discharge. The 100- and 500-year discharges resulted in unsubmerged orifice flow. Contraction scour at bridges with orifice flow is best estimated by use of the Chang pressureflow scour equation (oral communication, J. Sterling Jones, October 4, 1996). Therefore, contraction scour for the 100- and 500-year discharges was computed by use of the Chang equation (Richardson and others, 1995, p. 145-146). In this case, the incipient roadoverflow model resulted in the worst case contraction scour with a scour depth of $0.3 \mathrm{ft}$. However, it was not the worst case total scour.

Abutment scour was computed by use of the Froehlich equation (Richardson and others, 1995, p. 48, equation 28). Variables for the Froehlich equation include the Froude number of the flow approaching the embankments, the length of the embankment blocking flow, and the depth of flow approaching the embankment less any roadway overtopping.

The length to depth ratio of the embankment blocking flow exceeded 25 for the right abutment at the 100-year discharge and both abutments at the 500-year discharge. Although the HIRE equation (Richardson and others, 1993, p. 50, equation 25) generally is applicable when this ratio exceeds 25, the results from the HIRE equation were not used. Hydraulic Engineering Circular 18 recommends that the HIRE equation be used only when field conditions at the bridge site are similar to those for which the HIRE equation was derived (Richardson and others, 1993). Since the equation was developed from Army Corp. of Engineers' data obtained for spurs dikes in the Mississippi River, the HIRE equation was not adopted for the narrow, incised, upland valley at this site. 


\section{Scour Results}
100-yr discharge 500-yr discharge
Incipient overtopping (Scour depths in feet)

Contraction scour:

Main channel

Live-bed scour

Clear-water scour

Depth to armoring

Left overbank

Right overbank
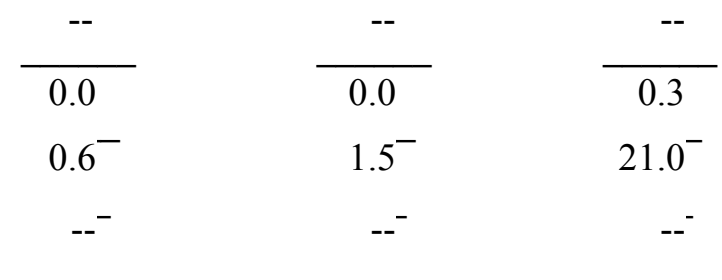

$21.0^{-}$

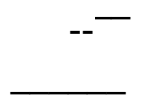

$--$

$--^{-}$

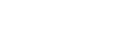

Local scour:

Abutment scour

Left abutment

8.0

7.3

8.6

9.4

8.9-

$6.2-$

\section{Right abutment}

Pier scour

Pier 1

Pier 2

Pier 3

Abutments:

Left abutment

Right abutment

Piers:

Pier 1

Pier 2

\section{Riprap Sizing}

Incipient overtopping 100-yr discharge 500-yrdischarge discharge

0.9 ( $D_{50}$ in feet)

\begin{tabular}{lcc}
0.9 & 1.2 & 1.8 \\
0.9 & 1.2 & 1.8 \\
\cline { 3 - 3 }- - $^{-}$ & $--^{-}$ & - - $^{-}$ \\
-- & -- & -- \\
-- & -- & -- \\
\hline
\end{tabular}




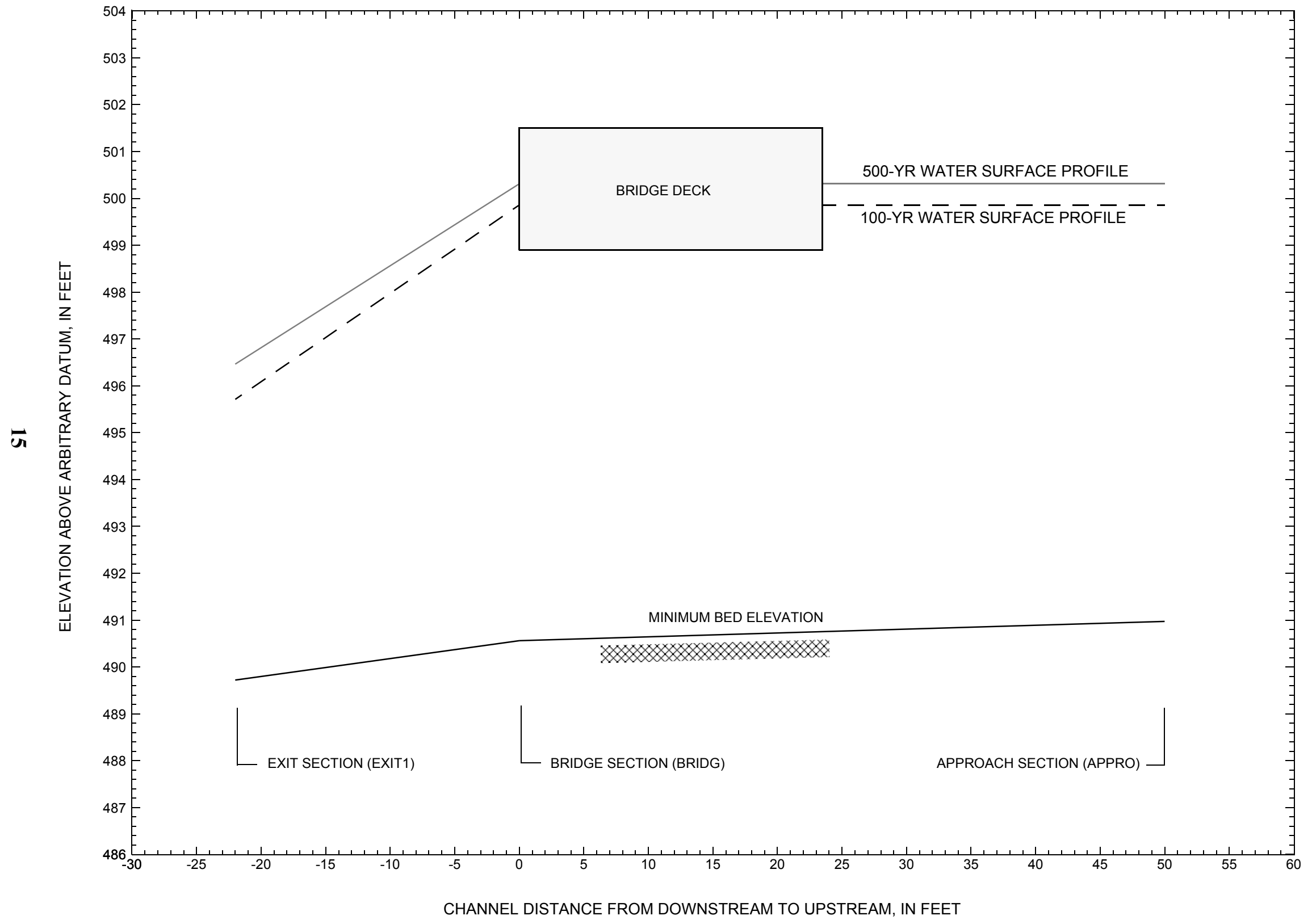

Figure 7. Water-surface profiles for the 100- and 500-yr discharges at structure CHARTH00010007 on town highway 1, crossing Mad Brook, Charleston, Vermont. 


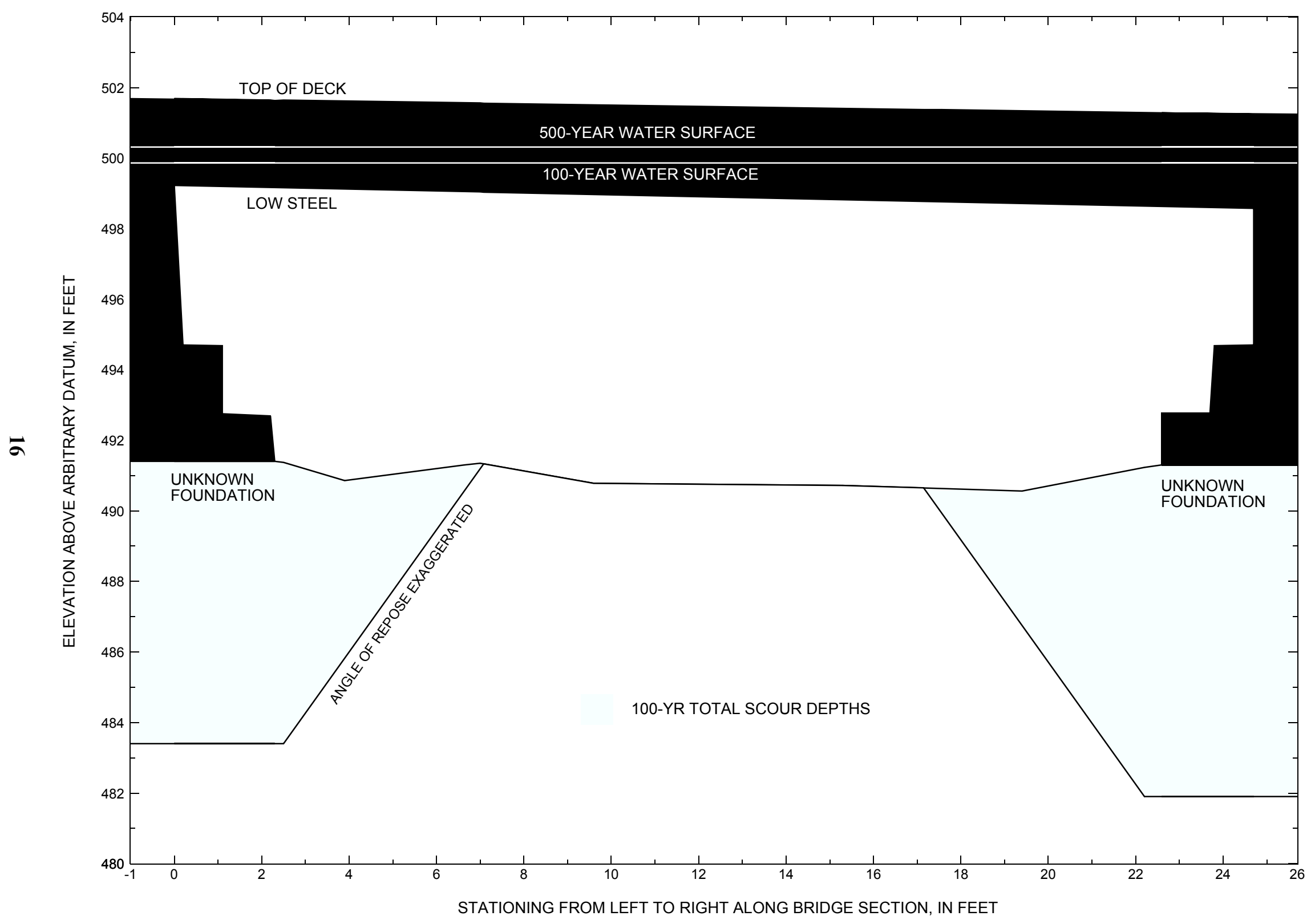

Figure 8. Scour elevations for the 100-year discharge at structure CHARTH00010007 on town highway 1, crossing Mad Brook, Charleston, Vermont. 
Table 1. Remaining footing/pile depth at abutments for the 100-year discharge at structure CHARTH00010007 on Town Highway 1, crossing Mad Brook, Charleston, Vermont.

[VTAOT, Vermont Agency of Transportation; --,no data]

\begin{tabular}{|c|c|c|c|c|c|c|c|c|c|c|c|}
\hline Description & Station $^{1}$ & $\begin{array}{l}\text { VTAOT } \\
\text { minimum } \\
\text { low-chord } \\
\text { elevation } \\
\text { (feet) }\end{array}$ & $\begin{array}{l}\text { Surveyed } \\
\text { minimum } \\
\text { low-chord } \\
\text { elevation } \\
\quad \text { (feet) }\end{array}$ & $\begin{array}{c}\text { Bottom of } \\
\text { footing } \\
\text { elevation } \\
\text { (feet) }\end{array}$ & $\begin{array}{c}\text { Channel } \\
\text { elevation at } \\
\text { abutment/ } \\
\text { pier }^{2} \\
\text { (feet) }\end{array}$ & $\begin{array}{l}\text { Contraction } \\
\text { scour depth } \\
\text { (feet) }\end{array}$ & $\begin{array}{l}\text { Abutment } \\
\text { scour } \\
\text { depth } \\
\text { (feet) }\end{array}$ & $\begin{array}{l}\text { Pier } \\
\text { scour } \\
\text { depth } \\
\text { (feet) }\end{array}$ & $\begin{array}{l}\text { Depth of } \\
\text { total scour } \\
\text { (feet) }\end{array}$ & $\begin{array}{c}\text { Elevation of } \\
\text { scour }^{2} \\
\text { (feet) }\end{array}$ & $\begin{array}{c}\text { Remaining } \\
\text { footing/pile } \\
\text { depth } \\
\text { (feet) }\end{array}$ \\
\hline \multicolumn{12}{|c|}{100 -yr. discharge is 1,300 cubic-feet per second } \\
\hline Left abutment & 0.0 & -- & 499.2 & -- & 491.4 & 0.0 & 8.0 & -- & 8.0 & 483.4 & -- \\
\hline Right abutment & 24.7 & -- & 498.6 & -- & 491.3 & 0.0 & 9.4 & -- & 9.4 & 481.9 & -- \\
\hline
\end{tabular}

1. Measured along the face of the most constricting side of the bridge.

2. Arbitrary datum for this study.

Table 2. Remaining footing/pile depth at abutments for the 500-year discharge at structure CHARTH00010007 on Town Highway 1, crossing Mad Brook, Charleston, Vermont.

[VTAOT, Vermont Agency of Transportation; --, no data]

\begin{tabular}{|c|c|c|c|c|c|c|c|c|c|c|c|}
\hline Description & Station $^{1}$ & $\begin{array}{l}\text { VTAOT } \\
\text { minimum } \\
\text { low-chord } \\
\text { elevation } \\
\text { (feet) }\end{array}$ & $\begin{array}{l}\text { Surveyed } \\
\text { minimum } \\
\text { low-chord } \\
\text { elevation } \\
\text { (feet) }\end{array}$ & $\begin{array}{c}\text { Bottom of } \\
\text { footing } \\
\text { elevation } \\
\text { (feet) }\end{array}$ & $\begin{array}{c}\text { Channel } \\
\text { elevation at } \\
\text { abutment/ } \\
\text { pier }^{2} \\
\text { (feet) }\end{array}$ & $\begin{array}{l}\text { Contraction } \\
\text { scour depth } \\
\text { (feet) }\end{array}$ & $\begin{array}{l}\text { Abutment } \\
\text { scour } \\
\text { depth } \\
\text { (feet) }\end{array}$ & $\begin{array}{l}\text { Pier } \\
\text { scour } \\
\text { depth } \\
\text { (feet) }\end{array}$ & $\begin{array}{l}\text { Depth of } \\
\text { total scour } \\
\text { (feet) }\end{array}$ & $\begin{array}{c}\text { Elevation of } \\
\text { scour }^{2} \\
\text { (feet) }\end{array}$ & $\begin{array}{c}\text { Remaining } \\
\text { footing/pile } \\
\text { depth } \\
\text { (feet) }\end{array}$ \\
\hline \multicolumn{12}{|c|}{500 -yr. discharge is 1,780 cubic-feet per second } \\
\hline Left abutment & 0.0 & -- & 499.2 & -- & 491.4 & 0.0 & 7.3 & -- & 7.3 & 484.1 & -- \\
\hline Right abutment & 24.7 & -- & 498.6 & -- & 491.3 & 0.0 & 8.9 & -- & 8.9 & 482.4 & -- \\
\hline
\end{tabular}

1. Measured along the face of the most constricting side of the bridge.

2. Arbitrary datum for this study. 


\section{SELECTED REFERENCES}

Arcement, G.J., Jr., and Schneider, V.R., 1989, Guide for selecting Manning's roughness coefficients for natural channels and flood plains: U.S. Geological Survey Water-Supply Paper 2339, 38 p.

Barnes, H.H., Jr., 1967, Roughness characteristics of natural channels: U.S. Geological Survey Water-Supply Paper 1849,213 p.

Benson, M. A., 1962, Factors Influencing the Occurrence of Floods in a Humid Region of Diverse Terrain: U.S. Geological Survey WaterSupply Paper 1580-B, 64 p.

Brown, S.A. and Clyde, E.S., 1989, Design of riprap revetment: Federal Highway Administration Hydraulic Engineering Circular No. 11, Publication FHWA-IP-89-016, 156 p.

Federal Highway Administration, 1983, Runoff estimates for small watersheds and development of sound design: Federal Highway Administration Report FHWA-RD-77-158

Froehlich, D.C., 1989, Local scour at bridge abutments in Ports, M.A., ed., Hydraulic Engineering--Proceedings of the 1989 National Conference on Hydraulic Engineering: New York, American Society of Civil Engineers, p. 13-18.

Hayes, D.C.,1993, Site selection and collection of bridge-scour data in Delaware, Maryland, and Virginia: U.S. Geological Survey WaterResources Investigation Report 93-4017, 23 p.

Johnson, C.G. and Tasker, G.D.,1974, Progress report on flood magnitude and frequency of Vermont streams: U.S. Geological Survey OpenFile Report 74-130, 37 p.

Lagasse, P.F., Schall, J.D., Johnson, F., Richardson, E.V., Chang, F., 1995, Stream Stability at Highway Structures: Federal Highway Administration Hydraulic Engineering Circular No. 20, Publication FHWA-IP-90-014, 144 p.

Laursen, E.M., 1960, Scour at bridge crossings: Journal of the Hydraulics Division, American Society of Civil Engineers, v. 86, no. HY2, p. 39-53.

Potter, W. D., 1957a, Peak rates of runoff in the Adirondack, White Mountains, and Maine woods area, Bureau of Public Roads

Potter, W. D., 1957b, Peak rates of runoff in the New England Hill and Lowland area, Bureau of Public Roads

Richardson, E.V. and Davis, S.R., 1995, Evaluating scour at bridges: Federal Highway Administration Hydraulic Engineering Circular No. 18, Publication FHWA-IP-90-017, 204 p.

Richardson, E.V., Simons, D.B., and Julien, P.Y., 1990, Highways in the river environment: Federal Highway Administration Publication FHWA-HI-90-016.

Ritter, D.F., 1984, Process Geomorphology: W.C. Brown Co., Debuque, Iowa, 603 p.

Shearman, J.O., 1990, User's manual for WSPRO--a computer model for water surface profile computations: Federal Highway Administration Publication FHWA-IP-89-027, 187 p.

Shearman, J.O., Kirby, W.H., Schneider, V.R., and Flippo, H.N., 1986, Bridge waterways analysis model; research report: Federal Highway Administration Publication FHWA-RD-86-108, 112 p.

Talbot, A.N., 1887, The determination of water-way for bridges and culverts.

U.S. Department of Transportation, 1993, Stream stability and scour at highway bridges, Participant Workbook: Federal Highway Administration Publication FHWA HI-91-011.

U.S. Geological Survey, 1988, Island Pond, Vermont 7.5 Minute Series quadrangle map: U.S. Geological Survey Topographic Maps, Aerial photography, 1983, Contour interval, 20 feet, Scale 1:24,000. 


\section{APPENDIX A: \\ WSPRO INPUT FILE}


WSPRO INPUT FILE

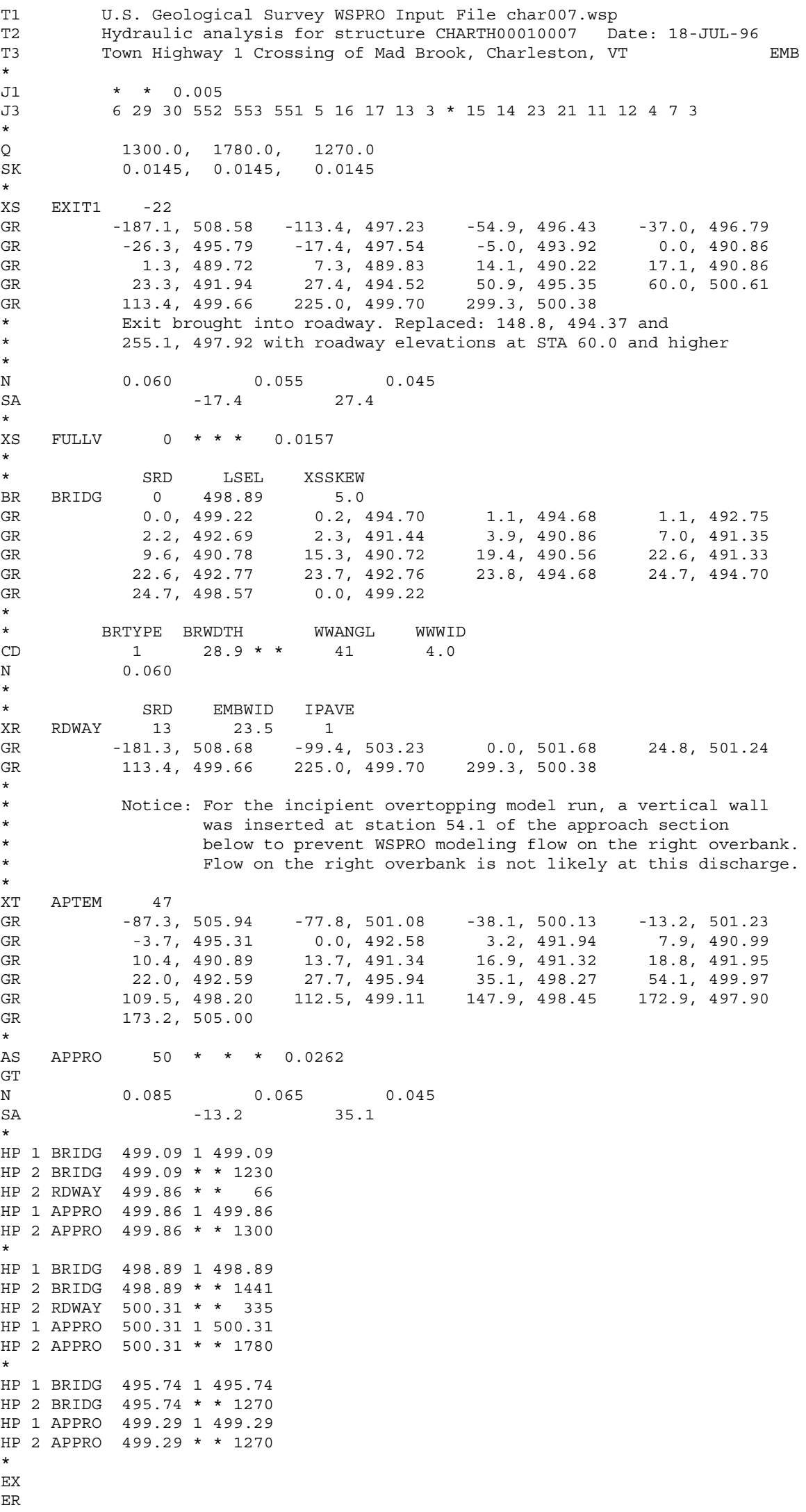




\section{APPENDIX B: \\ WSPRO OUTPUT FILE}


WSPRO OUTPUT FILE

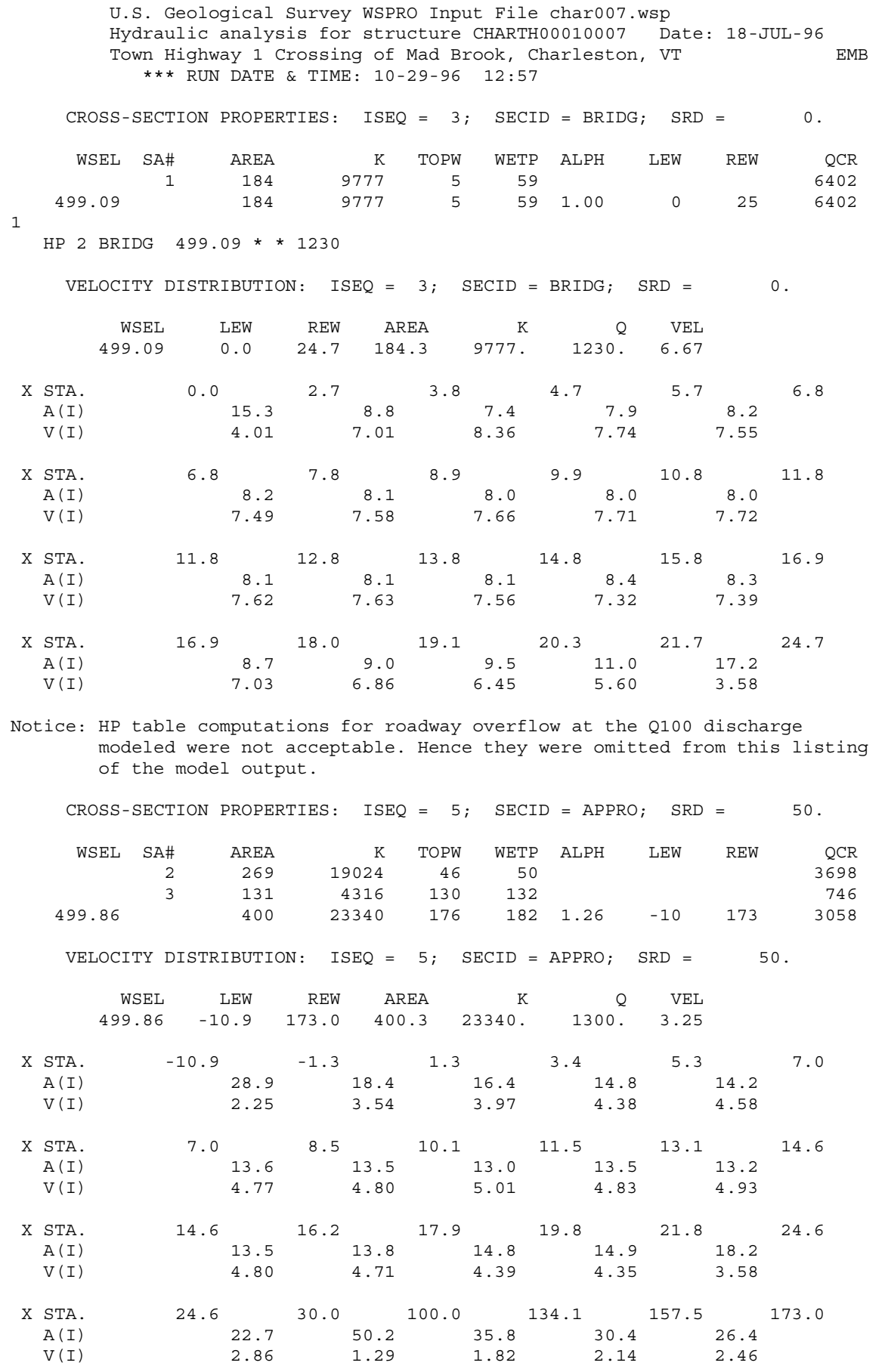


WSPRO OUTPUT FILE (continued)

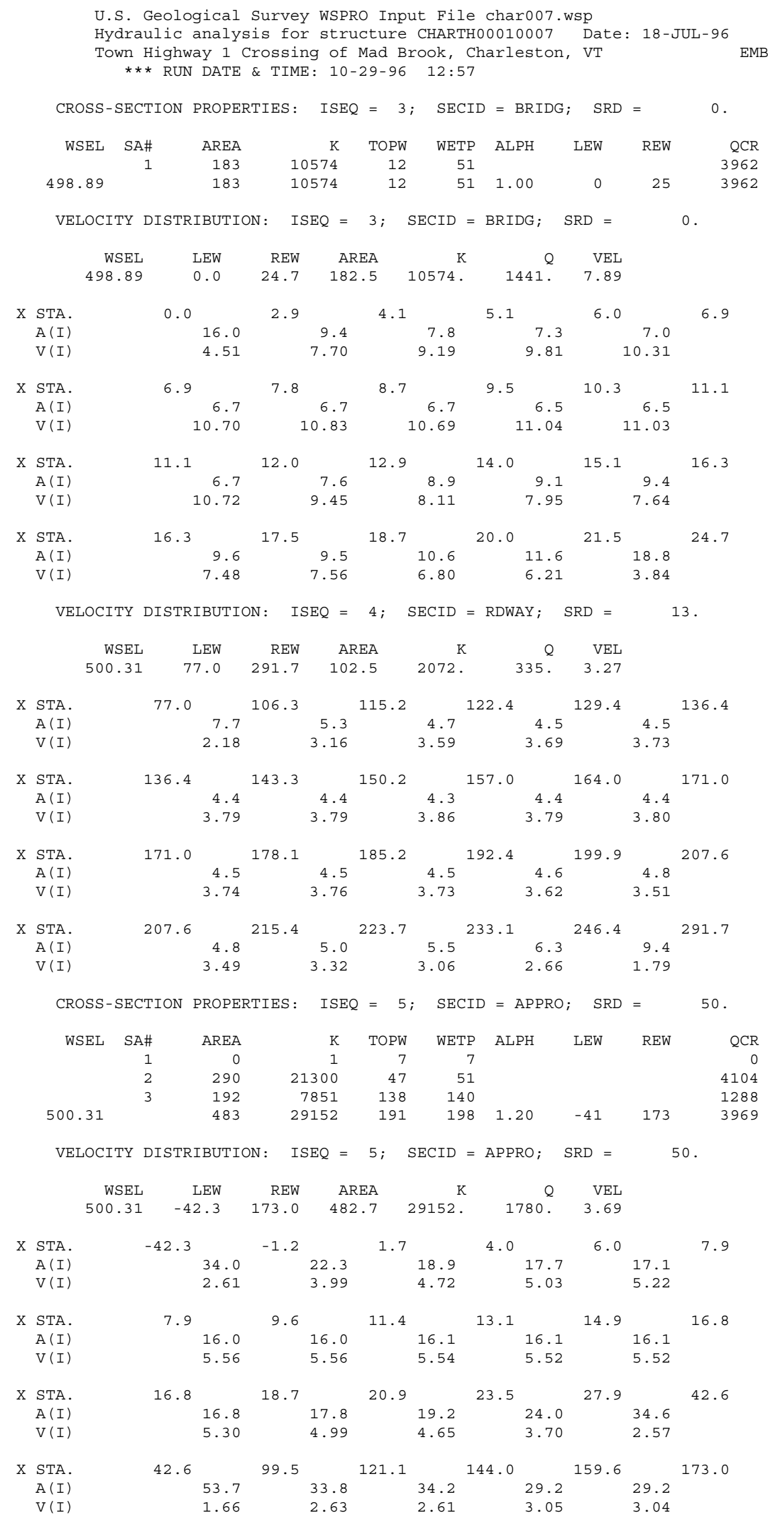


WSPRO OUTPUT FILE (continued)

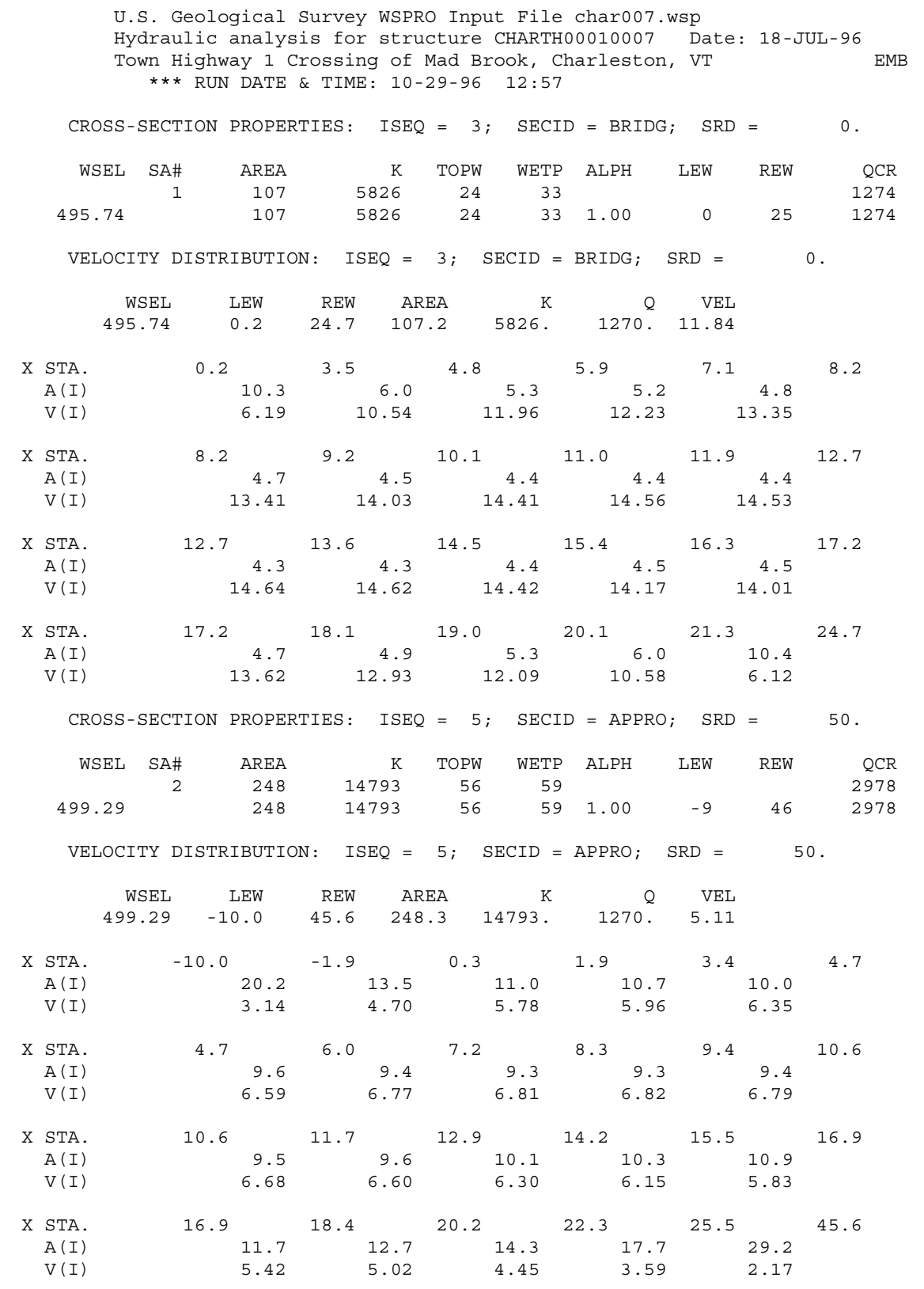


WSPRO OUTPUT FILE (continued)

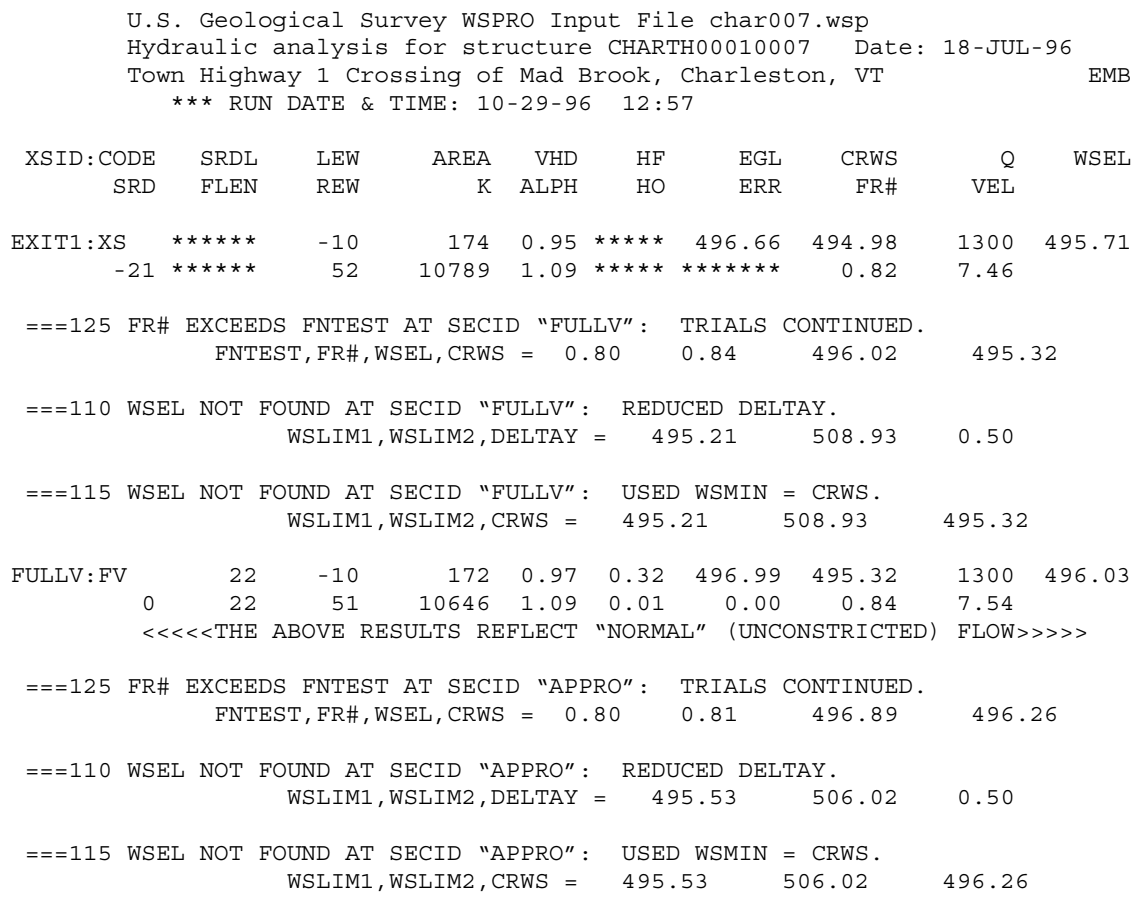

\begin{tabular}{|c|c|c|c|c|c|c|c|c|}
\hline XSID : CODE & SRD & LEW & REW & $Q$ & $\mathrm{~K}$ & AREA & VEL & WSEL \\
\hline EXIT1:XS & -22 & -11 & 52. & 1300. & 10789. & 174. & 7.46 & 495.71 \\
\hline FULLV : FV & 0. & -11. & 51. & 1300. & 10646 . & 172 . & 7.54 & 496.03 \\
\hline BRIDG : BR & 0 . & 0 . & 25 . & 1230. & 9775. & 184. & 6.67 & 499.09 \\
\hline RDWAY : RG & $13 . *$ & 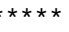 & 0 . & 66. & 0 . & $* * * * *$ & 1.00 & 499.86 \\
\hline APPRO : AS & 50. & -11 & 173. & 1300. & 23391. & 401. & 3.24 & 499.86 \\
\hline XSID : CODE & XLKQ & $\mathrm{XRKQ}$ & & & & & & \\
\hline
\end{tabular}




\section{WSPRO OUTPUT FILE (continued)}

SECOND USER DEFINED TABLE.

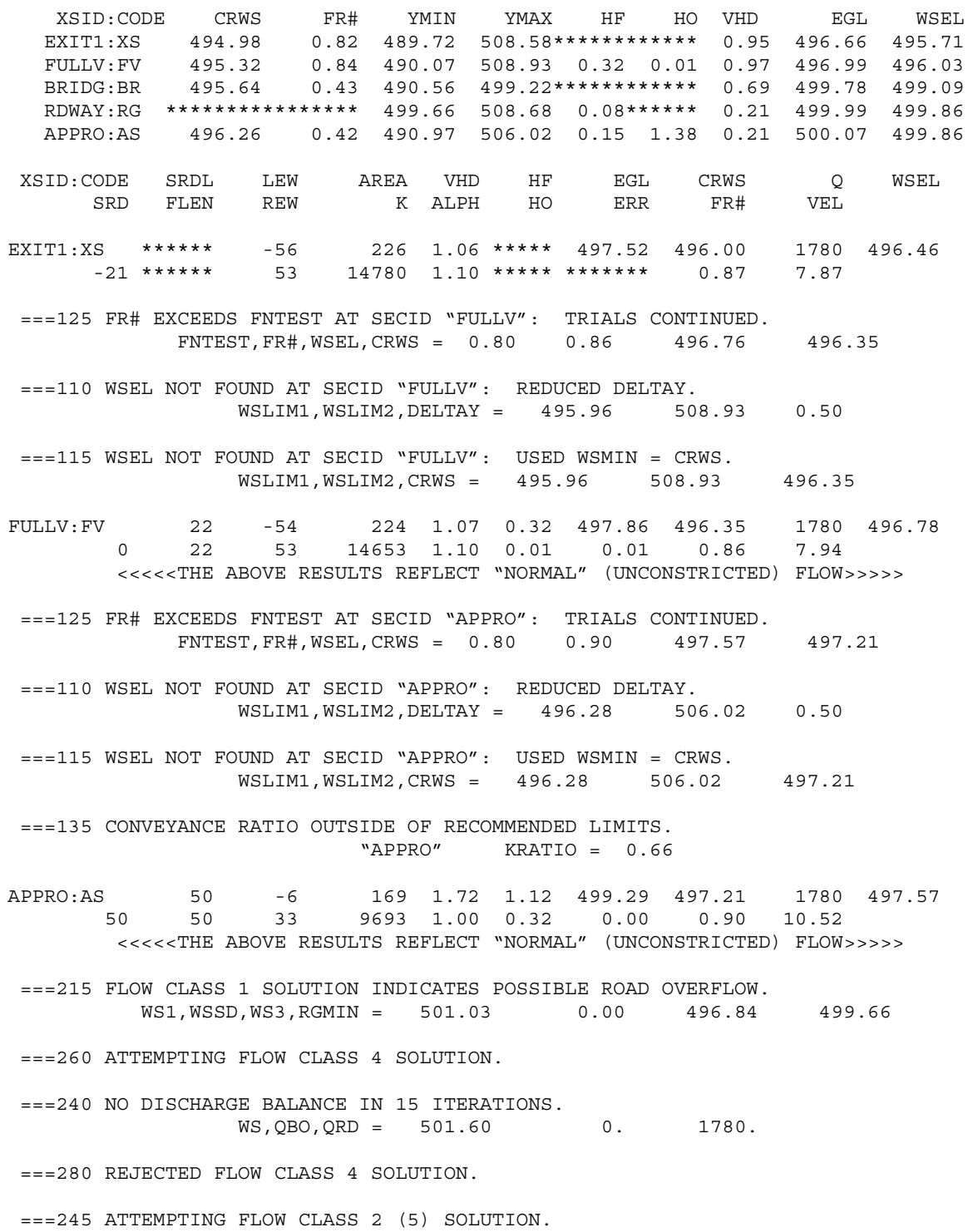

«<<<RESULTS REFLECTING THE CONSTRICTED FLOW FOLLOW $\gg>>>>$

\begin{tabular}{|c|c|c|c|c|c|c|c|c|c|c|c|c|}
\hline XSID : CODE & & RDL & LEW & AREA & VHD & $\mathrm{HF}$ & & EGL & CRWS & & Q & WSEL \\
\hline SRD & & LEN & REW & $\mathrm{K}$ & ALPH & HO & & ERR & FR\# & & VEL & \\
\hline BRIDG : BR & & 22 & 0 & 183 & 0.97 * & $\star * \star * *$ & & 99.86 & 496.13 & & 1441 & 498.89 \\
\hline 0 & $\star * * *$ & $\star \star *$ & 25 & 10574 & 1.00 * & $* * * * *$ & $\star * * *$ & 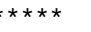 & 0.51 & & 7.89 & \\
\hline TYPE PI & PPCD & FLOW & C & $\mathrm{P} / \mathrm{A}$ & LSEL & $\mathrm{BL}$ & EN & XLAB & XRA & & & \\
\hline 1. $*$ & $\star * \star *$ & 5. & 0.432 & 0.000 & 498.89 & $39 \star \star \star \star *$ & & 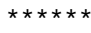 & 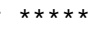 & & & \\
\hline XSID : COI & ODE & SRD & FLEN & $\mathrm{HF}$ & VHD & EGI & & $\mathrm{ERR}$ & & Q & WSEL & \\
\hline RDWAY : RG & & 13. & 27. & 0.10 & 0.25 & $500.4^{\circ}$ & & 0.00 & 33 & 5. & 500.31 & \\
\hline & $Q$ & WLEN & LEW & REW & DMAX & DAVC & & VMAX & VAVG & HAVG & CAVG & \\
\hline LT: & 0 . & 35. & -22 . & 13. & 0.6 & 0. & & 4.0 & 7.2 & 0.7 & 3.1 & \\
\hline RT : & 335. & 215. & 77. & 292. & 0.7 & 0. & & 3.7 & 3.3 & 0.6 & 3.1 & \\
\hline XSID : CODE & & RDL & LEW & AREA & VHD & $\mathrm{HF}$ & & EGL & CRWS & & Q & WSEL \\
\hline SRD & & LEN & REW & K & $\mathrm{ALPH}$ & $\mathrm{HO}$ & & ERR & FR\# & & VEL & \\
\hline APPRO: AS & & 21 & -41 & 483 & 0.25 & 0.18 & & 0.56 & 497.21 & & 1780 & 500.31 \\
\hline 50 & & 22 & 173 & 29154 & 1.20 & 0.00 & & 0.00 & 0.45 & & 3.69 & \\
\hline$M(G)$ & & $M(K)$ & $\mathrm{KQ}$ & XLKQ & XRKQ & & TEL & & & & & \\
\hline . & & & & & & & & & & & & \\
\hline
\end{tabular}


WSPRO OUTPUT FILE (continued)

FIRST USER DEFINED TABLE.

\begin{tabular}{|c|c|c|c|c|c|c|c|c|}
\hline XSID: CODE & SRD & LEW & REW & $Q$ & K & AREA & VEL & WSEL \\
\hline EXIT1:XS & -22 & -57 & 53. & 1780. & 14780. & 226 & 7.87 & 496.46 \\
\hline FULLV : FV & 0 . & -55 & 53. & 1780. & 14653. & 224 & 7.94 & 496.78 \\
\hline BRIDG : BR & 0 . & 0. & 25 . & 1441. & 10574 . & 183. & 7.89 & 498.89 \\
\hline RDWAY : RG & $13 . *$ & 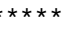 & 0 . & 335. & 0 . & 0 . & 1.00 & 500.31 \\
\hline APPRO : AS & 50. & -42 & 173. & 1780. & 29154 . & 483. & 3.69 & 500.31 \\
\hline XSID:CODE & XLKQ & XRKQ & & & & & & \\
\hline
\end{tabular}

SECOND USER DEFINED TABLE.

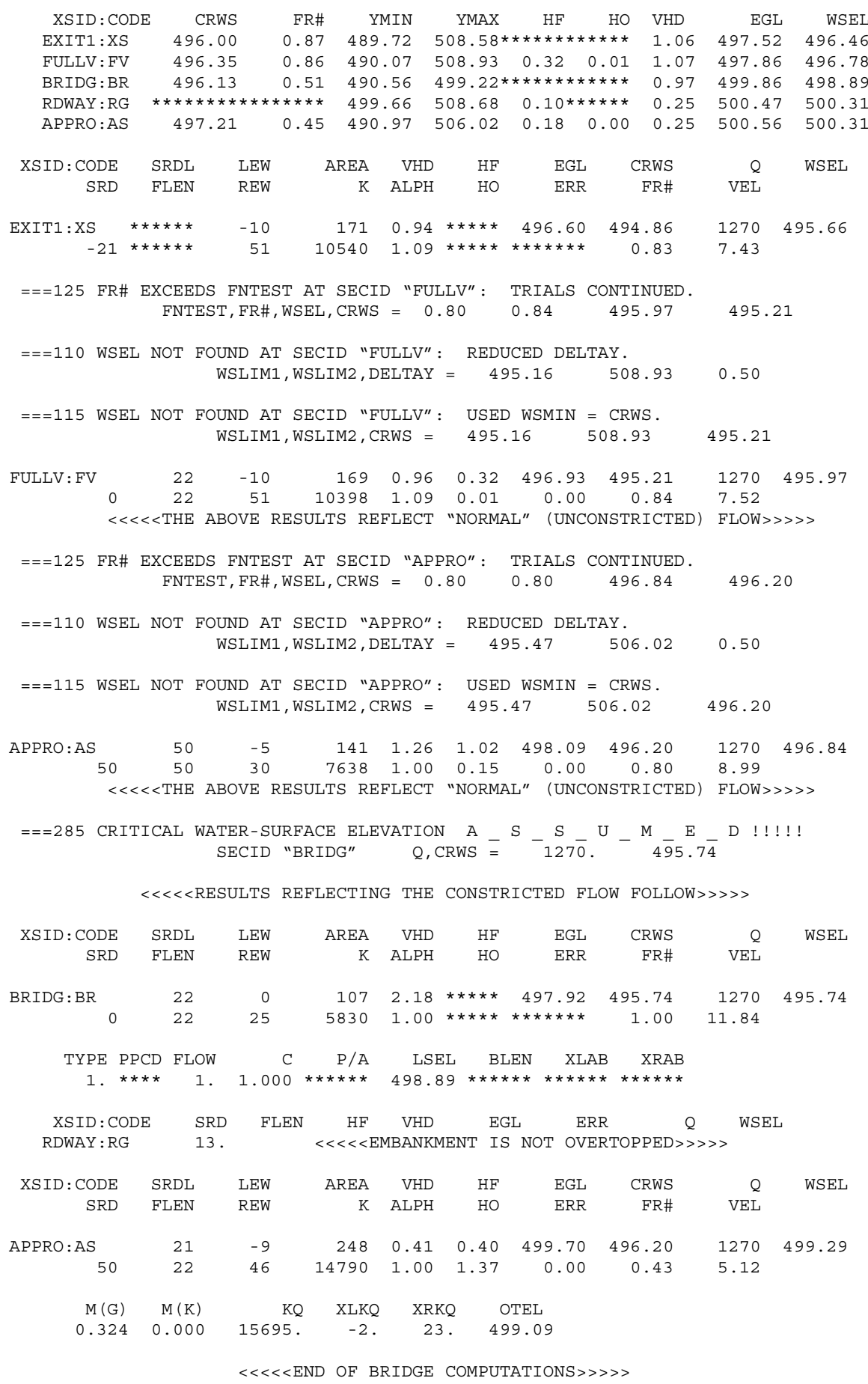


WSPRO OUTPUT FILE (continued)

FIRST USER DEFINED TABLE.

\begin{tabular}{|c|c|c|c|c|c|c|c|c|}
\hline XSID : CODE & SRD & LEW & REW & $Q$ & $\mathrm{~K}$ & AREA & VEL & WSEL \\
\hline EXIT1:XS & -22 & -11 & 51. & 1270. & 10540. & 171. & 7.43 & 495.66 \\
\hline FULLV : FV & 0 . & -11 & 51. & 1270. & 10398. & 169. & 7.52 & 495.97 \\
\hline BRIDG : BR & 0 . & 0 . & 25 . & 1270. & 5830. & 107. & 11.84 & 495.74 \\
\hline RDWAY : RG & \multicolumn{3}{|c|}{ 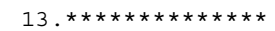 } & \multicolumn{3}{|c|}{ 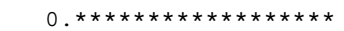 } & \multicolumn{2}{|c|}{$1.00 * * * * * * * *$} \\
\hline APPRO: AS & 50. & -10 & 46. & 1270. & 14790. & 248 & 5.12 & 499.29 \\
\hline XSID : CODE & XLKQ & XRKQ & & & & & & \\
\hline APPRO: AS & -2 . & 23. & 1569 & & & & & \\
\hline
\end{tabular}

SECOND USER DEFINED TABLE.

\begin{tabular}{|c|c|c|c|c|c|c|c|c|c|}
\hline XSID : CODE & CRWS & FR\# & YMIN & YMAX & $\mathrm{HF}$ & $\mathrm{HO}$ & VHD & EGL & WSEL \\
\hline EXIT1:XS & 494.86 & 0.83 & 489.72 & 508.58 * & 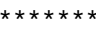 & $\star \star \star \star * *$ & 0.94 & 496.60 & 495.66 \\
\hline FULLV : FV & 495.21 & 0.84 & 490.07 & 508.93 & 0.32 & 0.01 & 0.96 & 496.93 & 495.97 \\
\hline BRIDG : BR & 495.74 & 1.00 & 490.56 & 499.22 * & $\star \star \star \star \star \star \star \star *$ & $\star \star \star \star \star *$ & 2.18 & 497.92 & 495.74 \\
\hline RDWAY : RG & 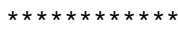 & $\star \star \star \star \star *$ & 499.66 & 508.68 * & 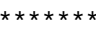 & $\star \star \star \star \star \star \star *$ & $\star \star \star \star \star \star *$ & 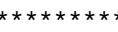 & 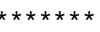 \\
\hline APPRO:AS & 496.20 & 0.43 & 490.97 & 506.02 & 0.40 & 1.37 & 0.41 & 499.70 & 499.29 \\
\hline 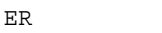 & & & & & & & & & \\
\hline
\end{tabular}




\section{APPENDIX C:}

\section{BED-MATERIAL PARTICAL-SIZE DISTRIBUTION}




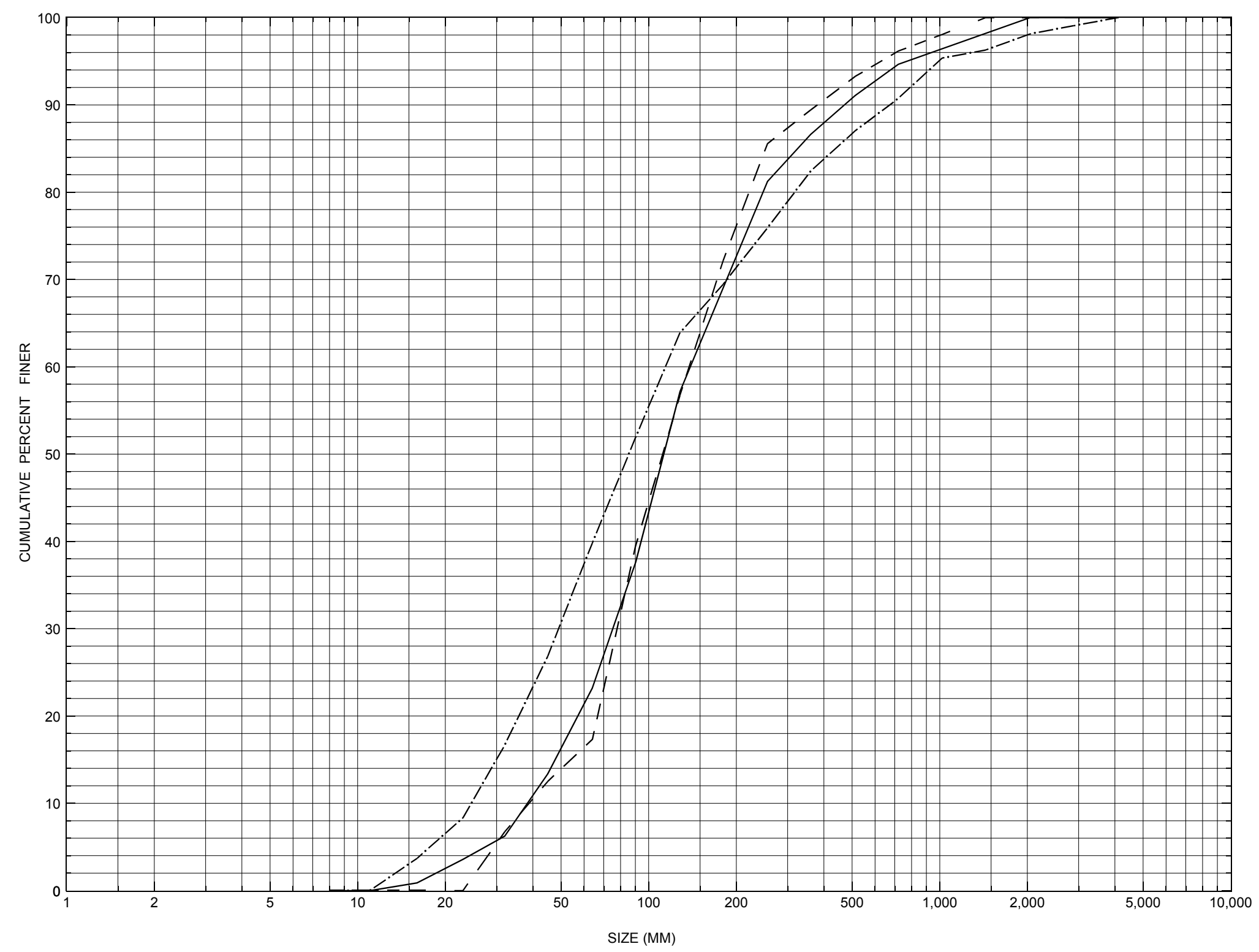

Appendix C. Bed material particle-size distributions for three pebble count transects at the approach cross-section for structure CHARTH00010007, in Charleston, Vermont. 


\section{APPENDIX D: \\ HISTORICAL DATA FORM}




\section{Structure Number CHARTH00010007}

\section{General Location Descriptive}

Data collected by (First Initial, Full last name) M. WEBER

Date $(M M / D D / Y Y) \_\mathbf{0 8} / \underline{\mathbf{0 4}} / \underline{\mathbf{9 4}}$

Highway District Number (I - 2; nn) $\mathbf{0 9}$

Town (FIPS place code; I - 4; nnnnn) 13150

Waterway (I - 6) Mad Brook

Route Number TH001

Topographic Map Island.Pond

Latitude (I - 16; nnnn.n) $\mathbf{4 4 4 9 0}$
County (FIPS county code; I - 3; nnn)

Mile marker (I - 11; nnn.nnn) $\mathbf{0 0 0 0 0 0}$

Road Name (I - 7): -

Vicinity (I - 9) 0.1 MI TO JCT W CL3 TH39

Hydrologic Unit Code: $\mathbf{0 1 1 1 0 0 0 0}$

Longitude (i - 17; nnnnn.n) $\mathbf{7 1 5 8 3}$

\section{Select Federal Inventory Codes}

FHWA Structure Number (I - 8) $\mathbf{1 0 1 0 0 4 0 0 0 7 1 0 0 4}$

Maintenance responsibility $(I-21 ; n n) \quad \mathbf{0 3}$

Year built (I - 27; YYYY) 1929

Average daily traffic, ADT (I - 29; nnnnnn) 000250

Year of ADT (I - 30; YY) $\mathbf{9 0}$

Opening skew to Roadway $(I-34 ; n n) \quad \mathbf{1 0}$

Operational status $(I-41 ; X)$ A

Structure type (I - 43; nnn) 104

Approach span structure type $(I-44 ; n n n) \quad \mathbf{0 0 0}$

Number of spans (I - 45; nnn) $\mathbf{0 0 1}$

Number of approach spans (I - 46; nnnn) $\mathbf{0 0 0 0}$

Comments:

The structural inspection report of 6/17/94 indicates the structure is a concrete T-beam type bridge. Some deep concrete spalling is noted on the wingwalls. The report notes a possibility that the left abutment has settled. There was no channel scour noted on the report of 6/17/94. However, a previous report on 9/17/92 indicated heavy channel scour. The report of 6/17/94 indicated that riprap is needed along the new subfootings. No point bars were noted.
Maximum span length (I - 48; nnnn) $\underline{\mathbf{0 0 2 5}}$

Structure length (I - 49; nnnnnn) $\underline{\mathbf{0 0 0 0 2 7}}$

Deck Width (I - 52; nn.n) 235

Channel \& Protection $(I-61 ; n) \underline{5}$

Waterway adequacy $(I-71 ; n) \underline{6}$

Underwater Inspection Frequency $(I-92 B ; X Y Y) \_$N

Year Reconstructed (I - 106) $\mathbf{0 0 0 0}$

Clear span (nnn.n ft) _

Vertical clearance from streambed (nnn.n ft) $\underline{\mathbf{0 0 7 . 7}}$

Waterway of full opening $\left(n n n . n \mathrm{ft}^{2}\right)$ 


\section{Bridge Hydrologic Data}

Is there hydrologic data available? $\underline{\mathbf{N}}$ if No, type ctrl- $n$ VTAOT Drainage area $\left(\mathrm{mi}^{2}\right)$ : -

Terrain character:

Stream character \& type: -

Streambed material: Stones, gravel, boulders

\begin{tabular}{ll} 
Discharge Data (cfs): & $\mathrm{Q}_{2.33}-$ \\
& $\mathrm{Q}_{50}-$ \\
\hline
\end{tabular}

Record flood date $(M M / D D / Y Y)$ : - $/$ - I -

$\begin{array}{ll}Q_{10} \_- & Q_{25} \_ \\ Q_{100 \_-} & Q_{500 \_}-\end{array}$

Water surface elevation $(f t):-$

Estimated Discharge (cfs):

Velocity at $\mathrm{Q}-$ $(\mathrm{ft} / \mathrm{s}):$

Ice conditions (Heavy, Moderate, Light) : Light

Debris (Heavy, Moderate, Light): Light

The stage increases to maximum highwater elevation (Rapidly, Not rapidly):

The stream response is (Flashy, Not flashy):

Describe any significant site conditions upstream or downstream that may influence the stream's stage: -

Watershed storage area (in percent): - _ \%

The watershed storage area is: - (1-mainly at the headwaters; 2- uniformly distributed; 3-immediatly upstream oi the site)

Water Surface Elevation Estimates for Existing Structure:

\begin{tabular}{|l|l|l|l|l|l|}
\hline Peak discharge frequency & $Q_{2.33}$ & $Q_{10}$ & $Q_{25}$ & $Q_{50}$ & $Q_{100}$ \\
Water surface elevation (ft)) & - & - & - & - & - \\
Velocity (ft/sec) & - & - & - & - & - \\
\hline
\end{tabular}

Long term stream bed changes: -

Is the roadway overtopped below the $\mathrm{Q}_{100}$ ? (Yes, No, Unknown): $\mathbf{U} \quad$ Frequency: -

Relief Elevation (ft):

Discharge over roadway at $Q_{100}\left(f^{3} / \mathrm{sec}\right)$ :

Are there other structures nearby? (Yes, No, Unknown): $\mathbf{U}$ Upstream distance (miles): Town: If No or Unknown, type ctrl-n os Highway No. : Structure No. : Year Built:

Clear span (ft): Clear Height (ft): Full Waterway $\left(f^{2}\right)$ : 
Downstream distance (miles): Town: Year Built:

Highway No. : Structure No. : Structure Type:

Clear span (ft): Clear Height $(f t)$ : Full Waterway $\left(f^{2}\right)$ :

Comments:

The water surface velocity at the time of the June 14, 1994 inspection was about 2 feet/second.

\section{USGS Watershed Data}

Watershed Hydrographic Data

Drainage area $(D A)$

6.59 $\mathrm{mi}^{2}$ Lake and pond area $\mathrm{mi}^{2}$

Watershed storage (ST) $\%$

Bridge site elevation 1196 $\mathrm{ft}$

Headwater elevation 3300 $\mathrm{ft}$

Main channel length 4.37 mi

$10 \%$ channel length elevation 1270 $\mathrm{ft} \quad 85 \%$ channel length elevation $\mathrm{ft}$

Main channel slope $(S)$

(S) 320.59 $\mathrm{ft} / \mathrm{mi}$

Watershed Precipitation Data

Average site precipitation in

Average headwater precipitation in

Maximum 2yr-24hr precipitation event $(124,2)$ in

Average seasonal snowfall (Sn) $\mathrm{ft}$ 


\section{Bridge Plan Data}

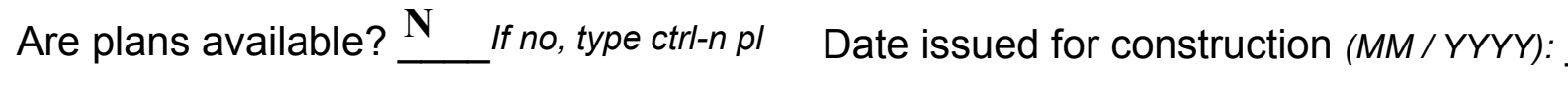

Project Number

Minimum channel bed elevation:

Low superstructure elevation: USLAB DSLAB USRAB DSRAB Benchmark location description:

-

Reference Point (MSL, Arbitrary, Other):

Datum (NAD27, NAD83, Other):

Foundation Type: 4

If 1 : Footing Thickness

If 2: Pile Type:

If 3: Footing bottom elevation:

Is boring information available? $\mathbf{N}$

Foundation Material Type: $\mathbf{3}$

(1-Spreadfooting; 2-Pile; 3- Gravity; 4-Unknown)

Footing bottom elevation: -

Briefly describe material at foundation bottom elevation or around piles:

NO FOUNDATION MATERIAL INFORMATION

Comments:

NO PLANS. 


\section{Cross-sectional Data}

Is cross-sectional data available? $\mathbf{N}$ If no, type ctrl-n xs

Source (FEMA, VTAOT, Other)? -

Comments: NO CROSS SECTION INFORMATION

\begin{tabular}{|l|l|l|l|l|l|l|l|l|l|l|l|}
\hline Station & - & - & - & - & - & - & - & - & - & - & - \\
\hline Feature & - & - & - & - & - & - & - & - & - & - & - \\
\hline $\begin{array}{l}\text { Low cord } \\
\text { elevation }\end{array}$ & - & - & - & - & - & - & - & - & - & - & - \\
\hline $\begin{array}{l}\text { Bed } \\
\text { elevation }\end{array}$ & - & - & - & - & - & - & - & - & - & - & - \\
\hline $\begin{array}{l}\text { Low cord to } \\
\text { bed length }\end{array}$ & - & - & - & - & - & - & - & - & - & - & - \\
\hline Station & - & - & - & - & - & - & - & - & - & - & - \\
\hline Feature & - & - & - & - & - & - & - & - & - & - & - \\
\hline $\begin{array}{l}\text { Low cord } \\
\text { elevation }\end{array}$ & - & - & - & - & - & - & - & - & - & - & - \\
\hline $\begin{array}{l}\text { Bed } \\
\text { elevation }\end{array}$ & - & - & - & - & - & - & - & - & - & - & - \\
\hline $\begin{array}{l}\text { Low cord to } \\
\text { bed length }\end{array}$ & - & - & - & - & - & - & - & - & - & - & - \\
\hline
\end{tabular}

Source (FEMA, VTAOT, Other)?

Comments: NO CROSS SECTION INFORMATION

\begin{tabular}{|l|l|l|l|l|l|l|l|l|l|l|l|}
\hline Station & - & - & - & - & - & - & - & - & - & - & - \\
\hline Feature & - & - & - & - & - & - & - & - & - & - & - \\
\hline $\begin{array}{l}\text { Low cord } \\
\text { elevation }\end{array}$ & - & - & - & - & - & - & - & - & - & - & - \\
\hline $\begin{array}{l}\text { Bed } \\
\text { elevation }\end{array}$ & - & - & - & - & - & - & - & - & - & - & - \\
\hline $\begin{array}{l}\text { Low cord to } \\
\text { bed length }\end{array}$ & - & - & - & - & - & - & - & - & - & - & - \\
\hline Station & - & - & - & - & - & - & - & - & - & - & - \\
\hline Feature & - & - & - & - & - & - & - & - & - & - & - \\
\hline $\begin{array}{l}\text { Low cord } \\
\text { elevation }\end{array}$ & - & - & - & - & - & - & - & - & - & - & - \\
\hline $\begin{array}{l}\text { Bed } \\
\text { elevation }\end{array}$ & - & - & - & - & - & - & - & - & - & - & - \\
\hline $\begin{array}{l}\text { Low cord to } \\
\text { bed length }\end{array}$ & - & - & - & - & - & - & - & - & - & - & - \\
\hline
\end{tabular}




\section{APPENDIX E: \\ LEVEL I DATA FORM}


U. S. Geological Survey

Bridge Field Data Collection and Processing Form

Qa/Qc Check by: $\mathbf{R B}$ Date: $2 / 13 / 96$

\section{Structure Number}

\section{A. General Location Descriptive}

1. Data collected by (First Initial, Full last name) M. WEBER

Date $(M M / D D / Y Y)$

$10 / 28 / 1994$

2. Highway District Number $\mathbf{0 9}$

County Orleans (019)

Mile marker -

Waterway (I - 6) Mad Brook

Town Charleston (13150)

Route Number TH 1

Road Name -

3. Descriptive comments:

Hydrologic Unit Code: $\mathbf{0 1 1 1 0 0 0 0}$

This structure is a concrete T-beam type bridge located about 0.1 mile from the intersection of TH 1 with TH 39.

\section{B. Bridge Deck Observations}
4. Surface cover... LBUS 5
RBUS 5
LBDS 4
RBDS 4
Overall 5

(2b us, ds,lb,rb: 1- Urban; 2- Suburban; 3- Row crops; 4- Pasture; 5- Shrub- and brushland; 6- Forest; 7- Wetland)
5. Ambient water surface... US $\underline{2}$
UB 2
DS $\underline{2}$
(1- pool; 2- riffle)

6. Bridge structure type 1 (1- single span; 2- multiple span; 3- single arch; 4- multiple arch; 5-cylindrical culvert; 6- box culvert; or 7- other)
7. Bridge length 27
(feet)
Span length 25
(feet)
Bridge width 23.5 (feet)

\section{Road approach to bridge:}
8. LB 2 RB 1
( 0 even, 1- lower, 2- higher)
9. $\mathrm{LB}$
RB 1
(1- Paved, 2- Not paved)

10. Embankment slope (run / rise in feet / foot):

US left

US right --

\begin{tabular}{|c|c|c|c|c|}
\hline & \multicolumn{2}{|c|}{ Protection } & \multirow{2}{*}{ 13.Erosion } & \multirow{2}{*}{ 14.Severity } \\
\hline & 11.Type & 12.Cond. & & \\
\hline LBUS & $\mathbf{0}$ & - & $\mathbf{0}$ & $\mathbf{0}$ \\
\hline RBUS & 1 & 1 & $\mathbf{0}$ & $\mathbf{0}$ \\
\hline RBDS & 1 & 1 & 2 & 1 \\
\hline LBDS & 1 & 2 & $\mathbf{0}$ & $\mathbf{0}$ \\
\hline
\end{tabular}

Bank protection types: 0 - none; 1- $<12$ inches;

2- < 36 inches; 3- < 48 inches;

4- < 60 inches; 5- wall / artificial levee

Bank protection conditions: 1- good; 2- slumped;

3- eroded; 4- failed

Erosion: 0 - none; 1- channel erosion; 2-

road wash; 3- both; 4- other

Erosion Severity: 0 - none; 1- slight; 2- moderate;

\section{Channel approach to bridge (BF):}

15. Angle of approach: $\mathbf{0}$

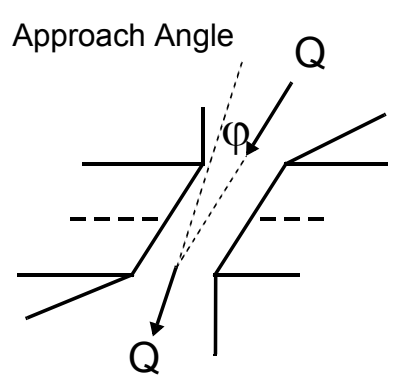

17. Channel impact zone 1:

Where? $(L B, R B)$

Range? feet -

Channel impact zone 2:

Where? $(L B, R B)$

Range? - $\quad$ feet Impact Severity: 0- none to very slight; 1- Slight; 2- Moderate; 3- Severe (US, UB, DS) to -

, DS) to - feet -

16. Bridge skew: 10 Bridge Skew Angle

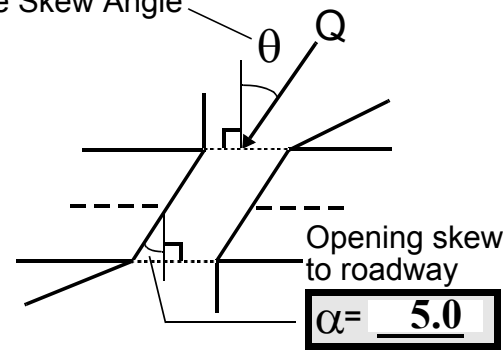

Exist? $\mathbf{N}(Y$ or $N)$

Severity (US, UB, DS) to feet -

Exist? $\mathbf{N}(Y$ or $N)$

Severity - 
18. Level II Bridge Type: $\underline{\mathbf{1 A} / \mathbf{4}}$

1a- Vertical abutments with wingwalls

$1 \mathrm{~b}$ - Vertical abutments without wingwalls

2- Vertical abutments and wingwalls, sloping embankment Wingwalls perpendicular to abut. face

3- Spill through abutments

4- Sloping embankment, vertical wingwalls and abutments Wingwall angle less than $90^{\circ}$.

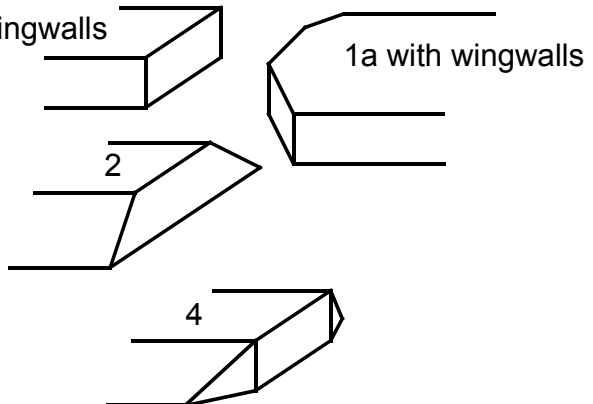

19. Bridge Deck Comments (surface cover variations, measured bridge and span lengths, bridge type variations, approach overflow width, etc.)

The bridge dimensions shown are from the VTAOT files. Field measurements of the bridge dimensions are 28.0 feet for the bridge length, 25.0 feet for the span length, and 23.5 feet for the roadway width.

Surface cover on the left bank upstream consists of mostly brush with trees on the bank. The upstream right bank surface cover is small trees and shrubs on the bank with tall grass and a gravel driveway on the overbank area. Surface cover downstream consists of mainly shrubs and brush near the bridge and pasture elsewhere.

The protection indicated on the upstream right and downstream left road embankments is located around the ends of the wingwalls. There is some protection around the end of the downstream right wingwall, which is covered by sand up to 1.5 feet thick. The class of this protection is approximated. A small hole has developed in the sand / protection, which is about 1 foot in diameter, 3 feet deep, and looks like it may have developed from road wash.

\section{Upstream Channel Assessment}

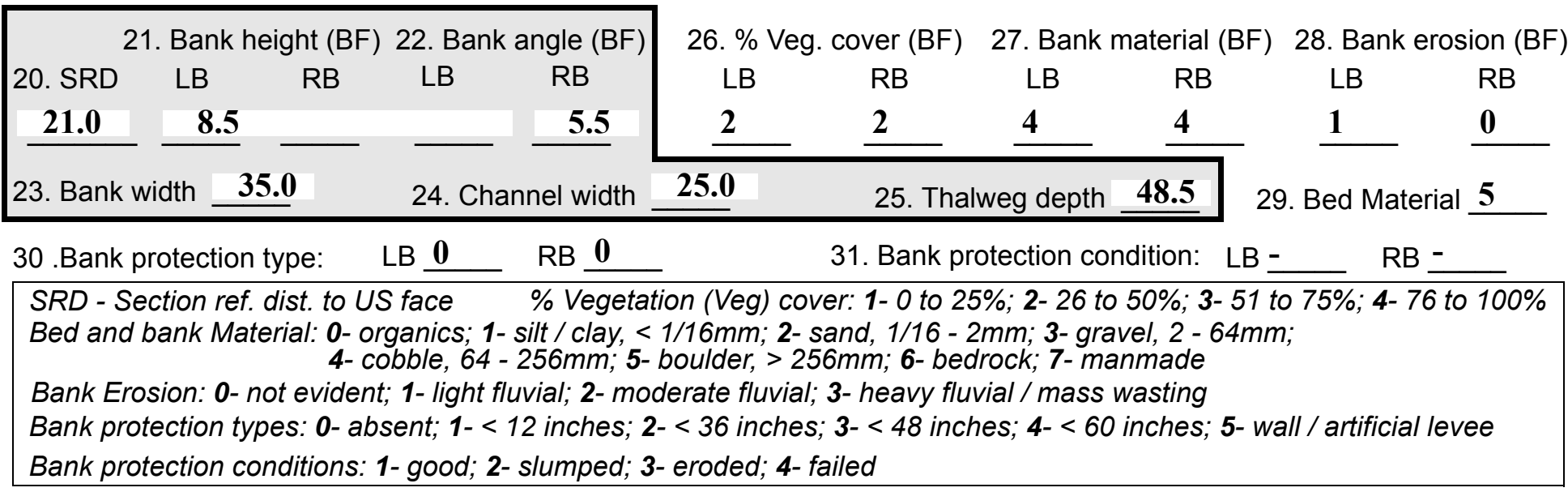

32. Comments (bank material variation, minor inflows, protection extent, etc.):

There is a waterfall type channel feature located over a bedrock outcrop about 275 feet upstream. The water falls approximately 10 feet as it proceeds over the falls.

27. The bank material is composed primarily of cobbles with a few boulders embedded in sand.

29. The bed material is boulder size mostly, with some cobbles embedded in sand and gravel.

28. There is some undercutting of the shrubs and trees on the left bank. 
33.Point/Side bar present? $\mathbf{N}(Y$ or $N$. if $N$ type ctrl-n pb)34. Mid-bar distance: -

35. Mid-bar width: -

36. Point bar extent: feet (US, UB) to feet (US, UB, DS) positioned $\%$ LB to $\% \mathrm{RB}$

37. Material: -

38. Point or side bar comments (Circle Point or Side; Note additional bars, material variation, status, etc.):

NO POINT BARS

39. Is a cut-bank present? $\underline{\mathbf{Y}}$ (Y or if $N$ type ctrl-n $c b)$

40. Where? $\mathbf{L B}$ (LB or RB)

41. Mid-bank distance: $\mathbf{5 2}$

42. Cut bank extent: 18

82 feet $\underline{\mathbf{U S}}$ (US, UB, DS)

43. Bank damage: 1

(1- eroded and/or creep; 2- slip failure; 3- block failure)

44. Cut bank comments (eg. additional cut banks, protection condition, etc.):

There is light bank cutting present with tree and shrub root systems exposed but holding material and preventing more extensive erosion. The old left abutment stonework extends 17 feet upstream probably preventing the cut bank from extending to the bridge. While there is some bank cutting here, there is no significant bend in the channel and hence no impact zone.

45. Is channel scour present? $\mathbf{N}$ (Y or if $N$ type ctrl-n cs) 46. Mid-scour distance: -
47. Scour dimensions: Length -
Width -
Depth : -
Position -
$\%$ LB to - $\% \mathrm{RB}$

48. Scour comments (eg. additional scour areas, local scouring process, etc.):

NO CHANNEL SCOUR

\section{Are there major confluences? $\mathbf{N}$}

51. Confluence 1: Distance Confluence 2: Distance 52. Enters on Enters on 54. Confluence comments (eg. confluence name):

\section{NO MAJOR CONFLUENCES}

50. How many? -

53. Type(1-perennial; 2- ephemeral)

Type (1-perennial; 2-ephemeral)

\section{Under Bridge Channel Assessment}

55. Channel restraint (BF)? LB 2

\begin{tabular}{|ccccc}
\hline \multicolumn{2}{|c}{56. Height (BF) } & \multicolumn{3}{c}{57 Angle (BF) } \\
LB & RB & LB & RB \\
$\mathbf{2 2 . 0}$ & & & $\mathbf{1 . 0}$ & \\
\hline
\end{tabular}
(1- natural bank; 2- abutment; 3- artificial levee)

58. Bank width (BF) 59. Channel width (Amb) \begin{tabular}{llll}
\multicolumn{2}{l}{ 61. Material (BF) } & \multicolumn{3}{l}{ 62. Erosion (BF) } \\
LB & RB & LB & RB \\
$\mathbf{2}$ & $\mathbf{7}$ & $\mathbf{7}$ & - \\
\hline
\end{tabular} 60. Thalweg depth $(\mathrm{Amb}) \quad \mathbf{9 0 . 0}$ 63. Bed Material -

Bed and bank Material: 0- organics; 1- silt / clay, < 1/16mm; 2- sand, 1/16 - 2mm; 3- gravel, 2 - 64mm; 4- cobble, 64 - 256mm; 5- boulder, > 256mm; 6- bedrock; 7- manmade

Bank Erosion: 0- not evident; 1- light fluvial; 2- moderate fluvial; 3- heavy fluvial / mass wasting

64. Comments (bank material variation, minor inflows, protection extent, etc.):

5

The bed material here is boulders mostly, embedded in sand and gravel with some cobbles. 
65. Debris and Ice Is there debris accumulation?

67. Debris Potential (1- Low; 2- Moderate; 3- High)

69. Is there evidence of ice build-up? 1

70. Debris and Ice Comments:

1

The channel reach is straight and steep upstream, which probably prevents extensive ice formation and blockage. There are no extensive cut banks and the channel is stable. Therefore, the potential for debris production is low, even though there is a high tree cover percentage on the banks.

\begin{tabular}{|l|c|c|c|c|c|c|c|c|}
\hline Abutments & $\begin{array}{c}\text { 71. Attack } \\
\angle \text { (BF) }\end{array}$ & $\begin{array}{c}\text { 72. Slope } \angle \\
\text { (Qmax) }\end{array}$ & $\begin{array}{c}\text { 73. Toe } \\
\text { loc. (BF) }\end{array}$ & $\begin{array}{c}\text { 74. Scour } \\
\text { Condition }\end{array}$ & $\begin{array}{c}75 . \text { Scour } \\
\text { depth }\end{array}$ & $\begin{array}{c}\text { 76. Exposure } \\
\text { depth }\end{array}$ & 77. Material & 78. Length \\
\hline LABUT & & - & $\mathbf{9 0}$ & $\mathbf{2}$ & $\mathbf{2}$ & $\mathbf{0 . 0}$ & $\mathbf{4 . 0}$ & $\mathbf{9 0 . 0}$ \\
\hline RABUT & $\mathbf{1}$ & $\mathbf{5}$ & $\mathbf{9 0}$ & & & $\mathbf{2}$ & $\mathbf{3}$ & $\mathbf{2 4 . 5}$ \\
\hline
\end{tabular}

Pushed: $L B$ or RB

Toe Location (Loc.): 0- even, 1- set back, 2- protrudes

Scour cond.: 0- not evident; 1- evident (comment); 2- footing exposed; 3-undermined footing; 4- piling exposed; 5- settled; 6- failed

Materials: 1- Concrete; 2- Stone masonry or drywall; 3- steel or metal; 4- wood

79. Abutment comments (eg. undermined penetration, unusual scour processes, debris, etc.):

$\mathbf{0 . 0}$

4.0

1

Both abutments have 2 newer subfootings each, which hide the original scour conditions and scour depths. The lower subfootings appear poured with minimal excavation. There is some minimal undermining (less than 2 inches) visible at the downstream end of the right abutment and at 6 feet under the bridge on the left abutment from the upstream face. The top of the upper footings are about 4 feet above the bed level at the thalweg under the bridge while that of the lower are about 2 feet above the bed level. Some old slab stonework protects the upstream left wingwall. The old stonework may be the construction material for the abutments of the original structure that were since refaced with concrete. The deck concrete appears in newer condition

80. Wingwalls:

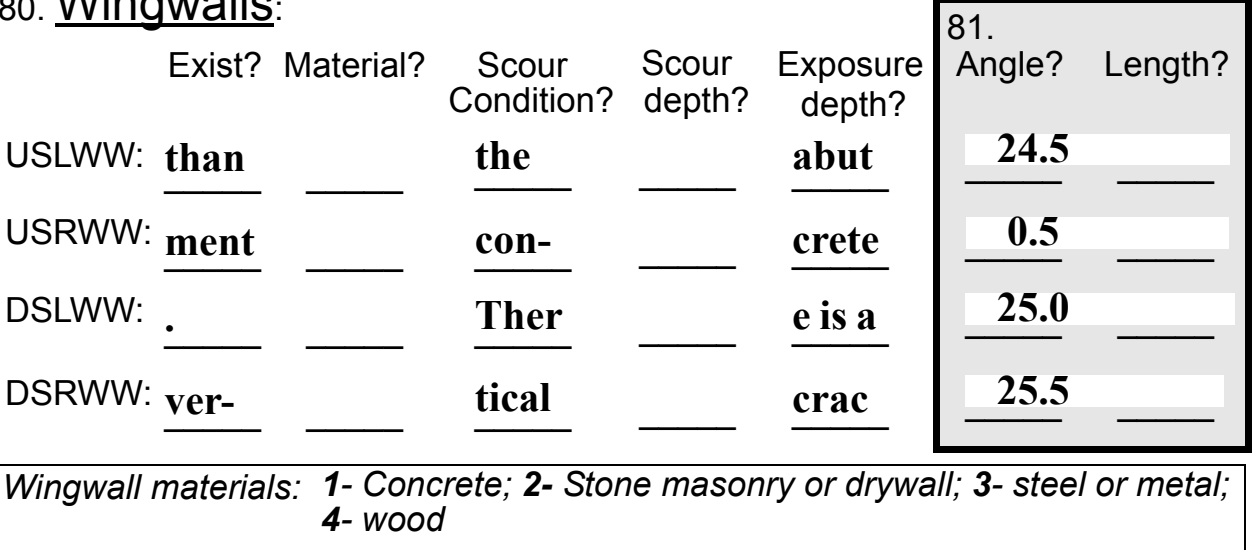

82. Bank / Bridge Protection:

\begin{tabular}{|l|l|l|l|l|l|l|l|l|}
\hline Location & USLWW & USRWW & LABUT & RABUT & LB & RB & DSLWW & DSRWW \\
\hline Type & $\mathbf{k}$ in & abut & wall & abo & feet & the & fro & upst \\
\hline Condition & the & men & loca & ut & und & brid & m & rea \\
\hline Extent & left & $\mathbf{t}$ & ted & $\mathbf{1 6}$ & er & ge & the & m \\
\hline
\end{tabular}

Bank / Bridge protection types: 0- absent; 1- < 12 inches; 2- < 36 inches; 3- < 48 inches; 4- < 60 inches; 5- wall / artificial levee

Bank / Bridge protection conditions: 1- good; 2- slumped; 3- eroded; 4- failed

Protection extent: 1- entire base length; 2- US end; 3- DS end; 4- other 
83. Wingwall and protection comments (eg. undermined penetration, unusual scour processes, etc.):

face. The crack is about one eighth of an inch wide and does not include the subfootings.

Y

1

0

$-$

$-$

$\mathbf{Y}$

1

2

0.0

4.0

\section{Piers:}

84. Are there piers? $\quad \mathbf{Y}$ (Y or if $N$ type ctrl-n pr)

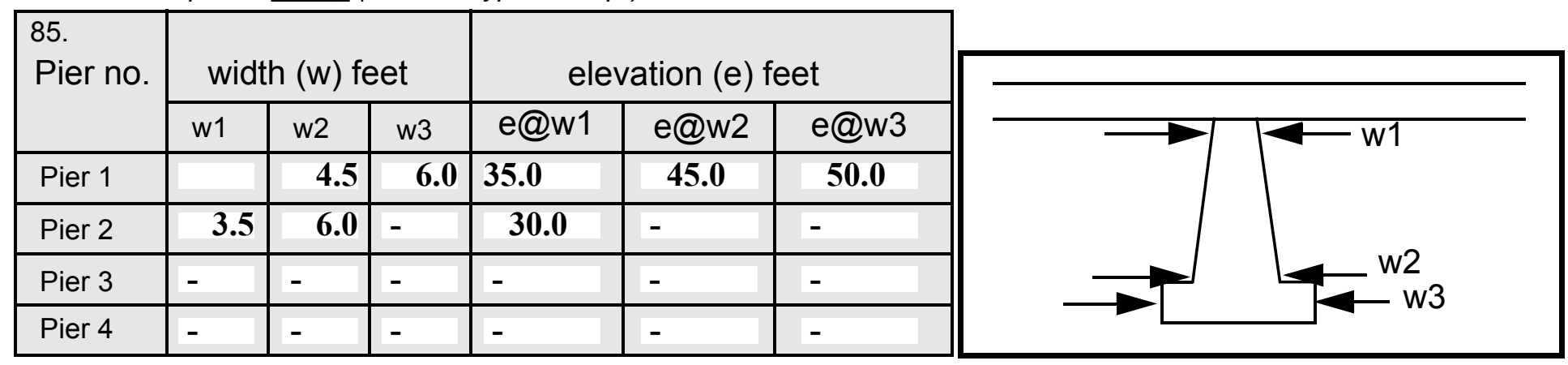

\begin{tabular}{|c|c|c|c|c|}
\hline Level 1 Pier Descr. & 1 & 2 & 3 & 4 \\
\hline 86. Location (BF) & 1 & 2 & - & $\mathbf{t}$ \\
\hline 87. Type & 2 & 1 & - & unde \\
\hline 88. Material & 0.0 & 1 & - & rmin \\
\hline 89. Shape & 4.0 & $\mathbf{0}$ & 2 & ing \\
\hline 90. Inclined? & $\mathbf{Y}$ & - & $\mathbf{1}$ & of $\mathbf{a}$ \\
\hline 91. Attack $\angle(\mathrm{BF})$ & 1 & - & 1 & few \\
\hline 92. Pushed & 2 & $\mathbf{0}$ & 2 & inch \\
\hline 93. Length (feet) & - & - & - & - \\
\hline 94. \# of piles & 0.0 & - & 1 & es or \\
\hline 95. Cross-members & 4.0 & - & 1 & less \\
\hline 96. Scour Condition & 2 & - & Som & is \\
\hline 97. Scour depth & 1 & - & e & reco \\
\hline 98. Exposure depth & 1 & - & sligh & gniz- \\
\hline
\end{tabular}

LFP, LTB, LB, MCL, MCM, MCR, RB, RTB, RFP

1- Solid pier, 2-column, 3- bent

1-Wood; 2- concrete; 3- metal; 4- stone

1- Round; 2- Square; 3- Pointed

Y-yes; $N$ - no

$L B$ or $R B$

0- none; 1- laterals; 2- diagonals; 3- both

0- not evident; 1- evident (comment);

2- footing exposed; 3- piling exposed;

4- undermined footing; 5- settled; 6-failed 
99. Pier comments (eg. undermined penetration, protection and protection extent, unusual scour processes, etc.):

able where the downstream right wingwall and right abutment meet. Like the abutments, the upstream and downstream right wingwalls have two subfootings that are two feet thick each. The subfootings possibly have masked the original scour conditions and depths. Only the upper subfooting on the downstream left wingwall is visible at the surface. The upstream left wingwall appears to have no subfootings and the concrete from the left abutment subfootings is molded around some very large native boulder material where the concrete ends at the upstream end of the left abutment. Protection on the upstream left wingwall consists of one, class 4 boulder, the old left abutment stonework, and a few native boulders. Concrete appears to have been poured over the old abutment walls. The concrete is spalling at all of the wingwalls except the upstream left wingwall.

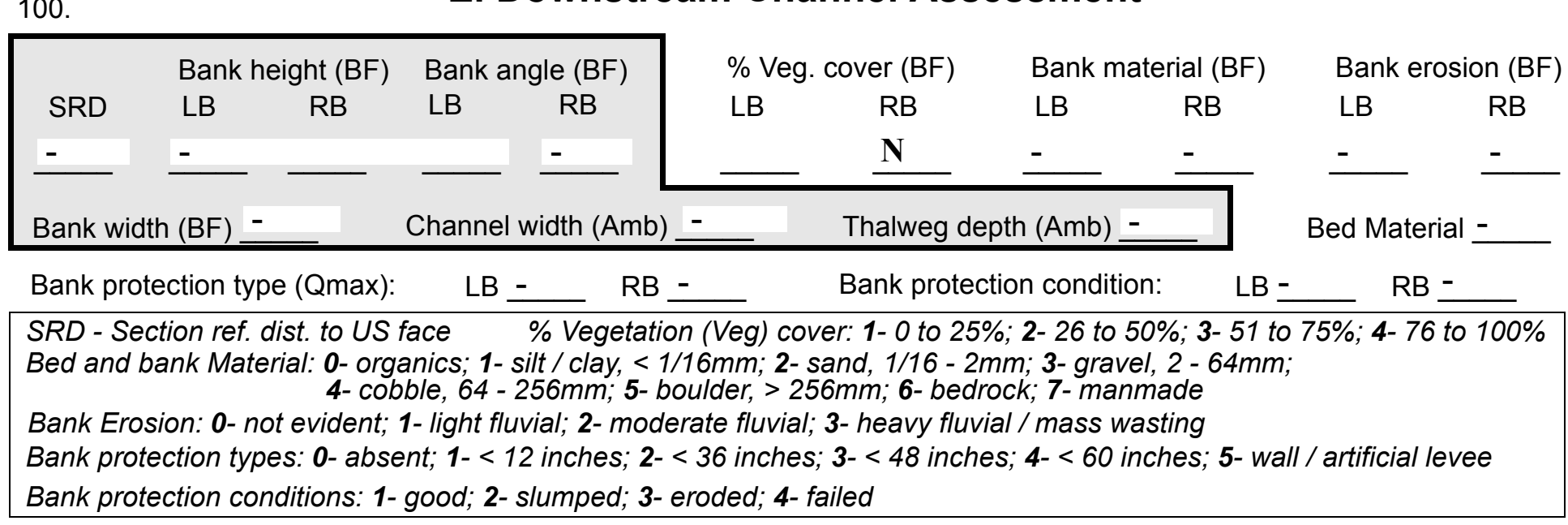

Comments (eg. bank material variation, minor inflows, protection extent, etc.):

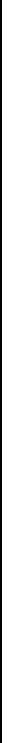

101. Is a drop structure present? _ _ ( or $N$, if $N$ type ctrl-n ds) 102. Distance: ___ feet 103. Drop: __ feet 104. Structure material: ___ (1- steel sheet pile; 2- wood pile; 3- concrete; 4- other) 105. Drop structure comments (eg. downstream scour depth): 
106. Point/Side bar present? (Y or $N$. if $N$ type ctrl-n pb)Mid-bar distance:

Mid-bar width: -

Point bar extent: feet -

(US, UB, DS) to feet (US, UB, DS) positioned $\%$ LB to $\% \mathrm{RB}$ Material:

Point or side bar comments (Circle Point or Side; note additional bars, material variation, status, etc.):

Is a cut-bank present? - (Y or if $N$ type ctrl-n $c b)$ Where? - _ (LB or RB) Mid-bank distance: NO Cut bank extent: $\underline{\text { PIE feet }}$ RS (US, UB, DS) to feet (US, UB, DS)

Bank damage: (1- eroded and/or creep; 2- slip failure; 3- block failure)

Cut bank comments (eg. additional cut banks, protection condition, etc.):

Is channel scour present? Scour dimensions: Length 2 Width 1 (Y or if $N$ type ctrl-n cs)

Mid-scour distance:

Scour comments (eg. additional scour areas, local scouring process, etc.):

o

4

2

0

Are there major confluences? 1 ( $Y$ or if $N$ type ctrl-n $m c)$

Confluence 1: Distance The

Confluence 2: Distance $\mathbf{k}$ Enters on left ( $L B$ or RB)

Enters on pro- $(L B$ or $R B)$

Positioned 4 $\%$ LB to $\underline{0}$ $\%$ RB Confluence comments (eg. confluence name):

tion consists of class 1 and 2 native (field) stone piled about 1 to 2 feet high in a wall type fashion extending to at least 300 feet downstream. There is a large sand deposit along the right bank from 15 to 46 feet down-

\section{F. Geomorphic Channel Assessment}

107. Stage of reach evolution str
1- Constructed

2- Stable

3- Aggraded

4- Degraded

5- Laterally unstable

6- Vertically and laterally unstable 
108. Evolution comments (Channel evolution not considering bridge effects; See HEC-20, Figure 1 for geomorphic descriptors):

eam. The bank material is composed of mainly cobbles with sand and gravel. The bed material is composed also of mainly cobbles with a few boulders embedded in sand and gravel. The cobble material on the right bank does not appear placed for protection of the bank. However, if it was placed, it is now slumped and eroded and is not nearly as extensive as the protection clearly present on the left bank. 


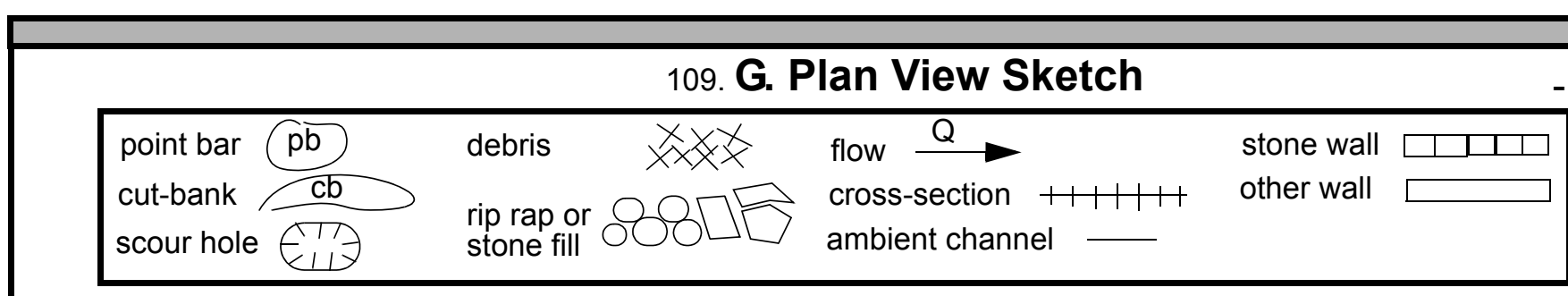


APPENDIX F:

SCOUR COMPUTATIONS 


\begin{tabular}{|c|c|c|c|}
\hline \multicolumn{2}{|l|}{ Structure Number: CHARTH00010007 } & Town : & CHARLESTON \\
\hline Road Number: & & County: & ORLEANS \\
\hline MAD BROOK & & & \\
\hline Initials EMB & \multicolumn{2}{|l|}{ Checked: } & \\
\hline \multicolumn{4}{|c|}{ Analysis of contraction scour, live-bed or clear water? } \\
\hline \multicolumn{2}{|c|}{$\begin{array}{l}\text { Critical Velocity of Bed Material (converted } \\
\text { Vc=11.21*y1^0.1667*D50^0.33 with } \mathrm{Ss}=2.65 \\
\text { (Richardson and others, 1995, p. 28, eq. 16) }\end{array}$} & to Engl & sh units) \\
\hline \multicolumn{4}{|l|}{ Approach Section } \\
\hline Characteristic & $100 \mathrm{yr}$ & $500 \mathrm{yr}$ & other $\mathrm{Q}$ \\
\hline Total discharge, cfs & 1300 & 1780 & 1270 \\
\hline Main Channel Area, ft2 & 269 & 290 & 248 \\
\hline Left overbank area, ft 2 & 0 & 0 & 0 \\
\hline Right overbank area, ft2 & 131 & 192 & 0 \\
\hline Top width main channel, ft & 46 & 47 & 56 \\
\hline Top width L overbank, ft & 0 & 7 & 0 \\
\hline Top width $\mathrm{R}$ overbank, ft & 130 & 138 & 0 \\
\hline D50 of channel, ft & 0.344 & 0.344 & 0.344 \\
\hline D50 left overbank, ft & 0 & 0 & 0 \\
\hline D50 right overbank, ft & 0 & 0 & 0 \\
\hline \multicolumn{2}{|c|}{ y1, average depth, MC, ft 5.8} & 6.2 & 4.4 \\
\hline \multirow{2}{*}{$\begin{array}{l}\text { y1, average depth, LOB, ft } \\
\text { y1, average depth, ROB, ft }\end{array}$} & ERR & 0.0 & ERR \\
\hline & 1.0 & 1.4 & ERR \\
\hline $\begin{array}{l}\text { Total conveyance, approach } \\
\text { Conveyance, main channel }\end{array}$ & 23340 & 29152 & 14793 \\
\hline Conveyance, main channel & 19024 & 21300 & 14793 \\
\hline Conveyance, LOB & 0 & 1 & 0 \\
\hline Conveyance, ROB & 4316 & 7851 & 0 \\
\hline Percent discrepancy, conveyance & 0.0000 & 0.0000 & 0.0000 \\
\hline \multirow{2}{*}{$\begin{array}{l}\text { Qm, discharge, MC, cfs } \\
\text { Ql, discharge, LOB, Cfs }\end{array}$} & 1059.6 & 1300.6 & 1270.0 \\
\hline & 0.0 & 0.1 & 0.0 \\
\hline Qr, discharge, ROB, cfs & 240.4 & 479.4 & 0.0 \\
\hline $\mathrm{Vm}$, mean velocity $\mathrm{MC}$, ft/s & 3.9 & 4.5 & 5.1 \\
\hline Vl, mean velocity, LOB, ft/s & ERR & ERR & ERR \\
\hline Vr, mean velocity, ROB, ft/s & 1.8 & 2.5 & ERR \\
\hline & 10.5 & 10.6 & 10.1 \\
\hline $\begin{array}{l}\text { Vc-m, crit. velocity, } \mathrm{MC}, \mathrm{ft} / \mathrm{s} \\
\text { Vc-l, crit. velocity, LOB, ft/s }\end{array}$ & $\mathrm{N} / \mathrm{A}$ & 0.0 & $\mathrm{~N} / \mathrm{A}$ \\
\hline Vc-r, crit. velocity, ROB, ft/s & 0.0 & 0.0 & $\mathrm{~N} / \mathrm{A}$ \\
\hline \multicolumn{4}{|l|}{ Results } \\
\hline Live-bed(1) or Clear-Water(0) Contr & action $\mathrm{Scc}$ & our? & \\
\hline Main Channel & 0 & 0 & 0 \\
\hline ARMORING & & & \\
\hline D90 & 1.622 & 1.622 & 1.622 \\
\hline D95 & 2.736 & 2.736 & 2.736 \\
\hline Critical grain size,Dc, ft & 0.2762 & 0.3885 & 1.1556 \\
\hline Decimal-percent coarser than Dc & 0.602 & 0.444 & 0.142 \\
\hline Depth to armoring, ft & 0.55 & 1.46 & 20.95 \\
\hline
\end{tabular}


Clear water Contraction Scour in MAIN CHANNEL

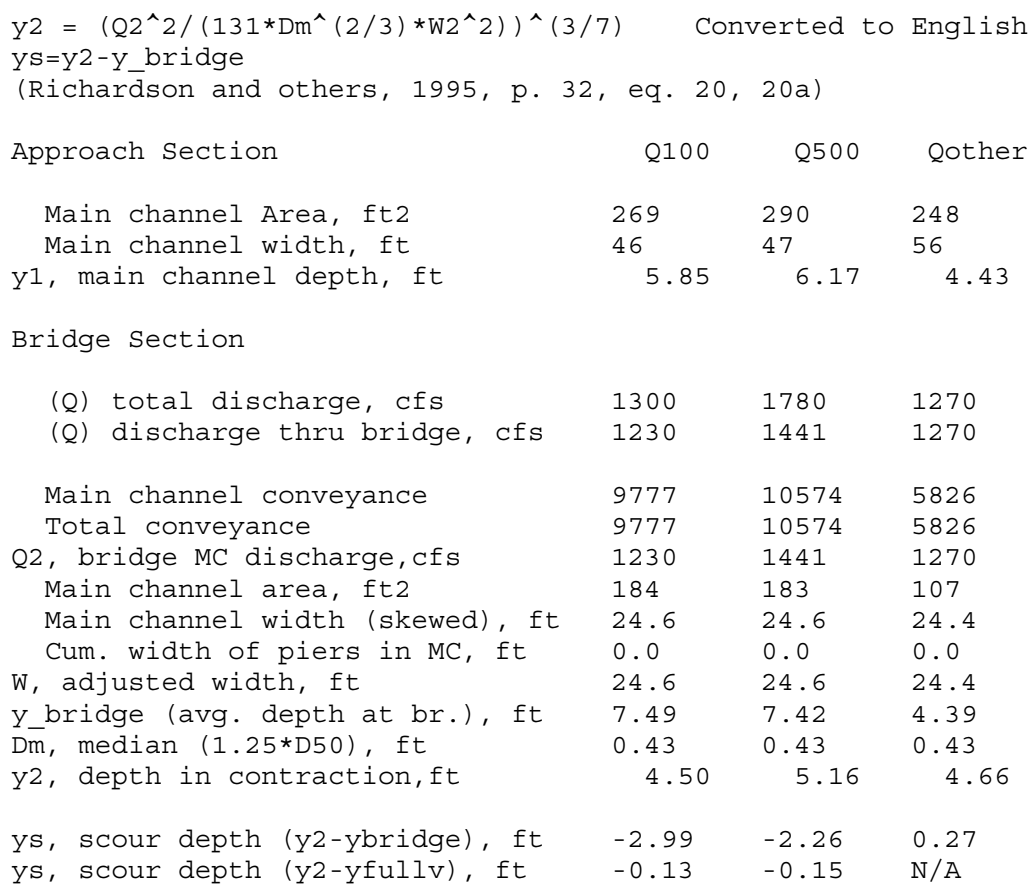

Pressure Flow Scour (contraction scour for orifice flow condtions)

\begin{tabular}{|c|c|c|c|}
\hline $\mathrm{Hb}+\mathrm{Ys}=\mathrm{Cq} * \mathrm{qbr} / \mathrm{Vc}$ & $\mathrm{Cf}=1$ & $5 * \operatorname{Fr}^{\wedge} 0.43$ & $3(<=1)$ \\
\hline $\begin{array}{l}\text { Chang Equation CC=SQRT }[0.10 *( \\
\text { (Richardson and others, 1995, p. } 14\end{array}$ & $\begin{array}{l}\mathrm{Hb} /(\mathrm{ya}-\mathrm{w}) \\
5-146)\end{array}$ & $-0.56)]+0$ & $(<=1)$ \\
\hline & Q100 & Q500 & OtherQ \\
\hline Q thru bridge main chan, cfs & 1230 & 1441 & 0 \\
\hline Vc, critical velocity, ft/s & 10.5 & 10.6 & 0 \\
\hline Vc, critical velocity, $\mathrm{m} / \mathrm{s}$ & 3.200244 & 3.230722 & 0 \\
\hline Main channel width (skewed), ft & 24.6 & 24.6 & 0 \\
\hline Cum. width of piers, ft & 0 & 0 & 0 \\
\hline w, adjusted width, ft & 24.6 & 24.6 & 0 \\
\hline qbr, unit discharge, $f t^{\wedge} 2 / \mathrm{s}$ & 50 & 58.57724 & ERR \\
\hline qbr, unit discharge, $\mathrm{m}^{\wedge} 2 / \mathrm{s}$ & 4.644699 & 5.441472 & $\mathrm{~N} / \mathrm{A}$ \\
\hline Area of full opening, $\mathrm{ft}^{\wedge} 2$ & 184.3 & 182.5 & 0 \\
\hline $\mathrm{Hb}$, depth of full opening, ft & 7.49187 & 7.418699 & $\mathrm{ERR}$ \\
\hline $\mathrm{Hb}$, depth of full opening, $\mathrm{m}$ & 2.283411 & 2.261109 & $\mathrm{~N} / \mathrm{A}$ \\
\hline Fr, Froude number $\mathrm{MC}$ & 0.43 & 0.51 & 1 \\
\hline Cf, Fr correction factor $(<=1.0)$ & 1 & 1 & 1.5 \\
\hline Elevation of Low steel, ft & 498.89 & 498.89 & 0 \\
\hline Elevation of Bed, ft & 491.3981 & 491.4713 & $\mathrm{~N} / \mathrm{A}$ \\
\hline Elevation of approach WS, ft & 499.86 & 500.31 & 0 \\
\hline HF, bridge to approach, ft & 0.15 & 0.18 & 0 \\
\hline Elevation of WS immediately US, ft & 499.71 & 500.13 & 0 \\
\hline ya, depth immediately US, ft & 8.31187 & 8.658699 & $\mathrm{~N} / \mathrm{A}$ \\
\hline ya, depth immediately US, m & 2.58293 & 2.690708 & $\mathrm{~N} / \mathrm{A}$ \\
\hline Mean elev. of deck, ft & 501.46 & 501.46 & 0 \\
\hline $\mathrm{w}$, depth of overflow, ft $(>=0)$ & 0 & 0 & 0 \\
\hline Cc, vert contrac correction $(<=1.0)$ & 0.974755 & 0.962276 & ERR \\
\hline Ys, depth of scour (chang), ft & -2.60664 & -1.67591 & $\mathrm{~N} / \mathrm{A}$ \\
\hline$y^{2}$, from Laursen equation, ft & 4.5 & 5.16 & 0 \\
\hline Full valley WSEL, ft & 496.03 & 496.78 & 0 \\
\hline Full valley depth (approx), ft & 4.63187 & 5.308699 & $\mathrm{~N} / \mathrm{A}$ \\
\hline ys, depth of scour (FULLV), ft & -0.13187 & -0.1487 & $\mathrm{~N} / \mathrm{A}$ \\
\hline
\end{tabular}


Abutment Scour

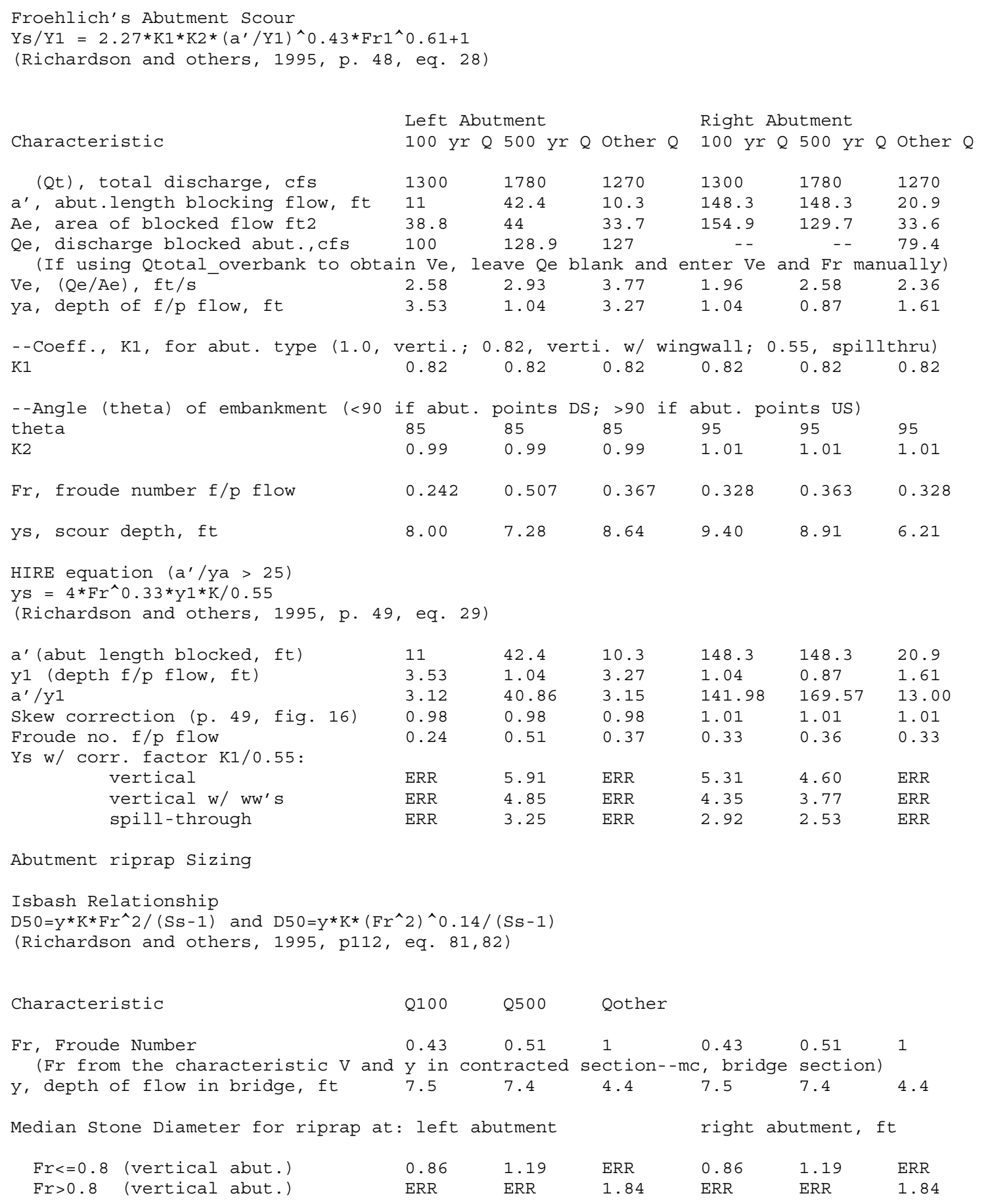

